\title{
IRAK1 Duplication in MECP2 Duplication Syndrome Does Not Increase Canonical NF-kB-Induced Inflammation
}

\section{Ilona Gottschalk}

Humboldt-Universität zu Berlin, and Berlin Institute of Health (BIH)

\section{Uwe Kölsch}

Labor Berlin GmbH, Department of Immunology

\section{Dimitrios L. Wagner}

Humboldt-Universität zu Berlin, and Berlin Institute of Health (BIH)

Jonas Kath

Humboldt-Universität zu Berlin, and Berlin Institute of Health (BIH)

\section{Stefania Martini}

Berlin Institute of Health (BIH)

\section{Renate Krüger}

Humboldt-Universität zu Berlin, and Berlin Institute of Health (BIH)

\section{Anne Puel}

University of Paris, Imagine Institute

\section{Jean-Laurent Casanova}

The Rockefeller University

\section{Aleksandra Jezela-Stanek}

National Institute of Tuberculosis and Lung Diseases

\section{Rainer Rossi}

Childrens' Hospital Neukölln, Vivantes $\mathrm{GmbH}$

\section{Salima El Chehadeh}

Institute of Medical Genetics of Alsace (IGMA)

\section{Hilde Van Esch}

University Hospitals Leuven

Horst von Bernuth ( $\nabla$ horst.von-bernuth@charite.de)

Charite Universitatsmedizin Berlin https://orcid.org/0000-0002-5812-7675

\section{Research Article}

Keywords: Xq28-duplication syndrome, methyl CpG binding protein 2 (MECP2) duplication syndrome, methyl CpG binding protein 2 (MECP2), interleukin-1 receptor-associated kinase 1 (IRAK1), canonical NF- 
$\mathrm{KB}$ signaling, inborn errors of immunity

Posted Date: March 3rd, 2022

DOI: https://doi.org/10.21203/rs.3.rs-1389483/v1

License: (c) (i) This work is licensed under a Creative Commons Attribution 4.0 International License. Read Full License 


\title{
IRAK1 Duplication in MECP2 Duplication Syndrome Does Not Increase Canonical NF-кB-Induced Inflammation
}

Ilona Gottschalk ${ }^{1,2}$, Uwe Kölsch ${ }^{3}$, Dimitrios L. Wagner ${ }^{2,4,5,6}$, Jonas Kath ${ }^{2,4}$, Stefania Martini ${ }^{2}$, Renate Krüger ${ }^{1}$, Anne Puel ${ }^{7,8}$, Jean-Laurent Casanova ${ }^{7,8,9,10,11}$, Aleksandra Jezela-Stanek ${ }^{12}$, Rainer Rossi ${ }^{13}$, Salima El Chehadeh ${ }^{14}$, Hilde Van Esch ${ }^{15}$, Horst von Bernuth ${ }^{1,2,3,16}$

\author{
${ }^{1}$ Department of Pediatric Respiratory Medicine, Immunology and Critical Care Medicine, Charité - Universitätsmedizin Berlin, corporate member of \\ Freie Universität Berlin, Humboldt-Universität zu Berlin, and Berlin Institute of Health (BIH), Berlin, Germany \\ ${ }^{2}$ BIH Center for Regenerative Therapies (BCRT), Berlin Institute of Health (BIH), Berlin, Germany \\ ${ }^{3}$ Labor Berlin GmbH, Department of Immunology, Berlin, Germany \\ ${ }^{4}$ Berlin Center for Advanced Therapies (BeCAT), Charité - Universitätsmedizin Berlin, corporate member of Freie Universität, Berlin, Humboldt- \\ Universität zu Berlin, and Berlin Institute of Health (BIH), Berlin, Germany \\ ${ }^{5}$ Institute of Transfusion Medicine, Charité - Universitätsmedizin Berlin, corporate member of Freie Universität Berlin, Humboldt-Universität zu Berlin, \\ and Berlin Institute of Health (BIH), Berlin, Germany \\ ${ }^{6}$ Institute of Medical Immunology, Campus Virchow-Klinikum, Charité - Universitätsmedizin Berlin, corporate member of Freie Universität Berlin, \\ Humboldt-Universität zu Berlin, and Berlin Institute of Health (BIH), Berlin, Germany \\ ${ }^{7}$ Laboratory of Human Genetics of Infectious Diseases, Necker Branch, INSERM U1163, Necker Hospital for Sick Children, Paris, France \\ ${ }^{8}$ University of Paris, Imagine Institute, Paris, France \\ ${ }^{9}$ St. Giles Laboratory of Human Genetics of Infectious Diseases, Rockefeller Branch, The Rockefeller University, New York, NY, USA \\ ${ }^{10}$ Howard Hughes Medical Institute, New York, NY, USA \\ ${ }^{11}$ Pediatric Hematology and Immunology Unit, Necker Hospital for Sick Children, AP-HP, Paris, France \\ ${ }^{12}$ Department of Genetics and Clinical Immunology, National Institute of Tuberculosis and Lung Diseases, Warsaw, Poland \\ ${ }^{13}$ Childrens’ Hospital Neukölln, Vivantes GmbH, Berlin, Germany \\ ${ }^{14}$ Institute of Medical Genetics of Alsace (IGMA), Strasbourg, France \\ ${ }^{15}$ Center for Human Genetics, University Hospitals Leuven, Leuven, Belgium \\ ${ }^{16}$ Berlin Institute of Health at Charité - Universitätsmedizin Berlin, Berlin, Germany
}

Corresponding author:

Horst von Bernuth, MD PhD

Department of Pediatric Respiratory Medicine, Immunology and Critical Care Medicine

Labor Berlin GmbH, Department of Immunology

Berlin Institute of Health (BIH), Berlin-Brandenburg Center for Regenerative Therapies (BCRT)

Charité - Universitätsmedizin Berlin

Augustenburger Platz 1

D-13353 Berlin

E-Mail: horst.von-bernuth@charite.de 


\begin{abstract}
Purpose Besides their developmental and neurological phenotype, most patients with MECP2/IRAK1 duplication syndrome present with recurrent and severe infections, accompanied by strong inflammation. Respiratory infections are the most common cause of death. Standardized pneumological diagnostics, targeted anti-infectious treatment and knowledge of the underlying pathomechanism that triggers strong inflammation are unmet clinical needs. We investigated the influence of IRAK1 overexpression on the canonical NF- $\mathrm{KB}$ signaling as a possible cause for excessive inflammation in these patients.

Methods NF- $\mathrm{KB}$ signaling was examined by measuring the production of proinflammatory cytokines as well as evaluating the IRAK1 phosphorylation and degradation as well as the IкB $\alpha$-degradation upon stimulation with IL- $1 \beta$ and TLR-agonists in SV40 immortalized fibroblasts, PBMCs and whole blood of 9 patients with MECP2/IRAK1 duplication syndrome, respectively.

Results Both, MECP2/IRAK1-duplicated patients and healthy controls, showed similar production of IL-6 and IL-8 upon activation with IL-1 $\beta$ and TLR4/2/6-agonists in immortalized fibroblasts, PBMCs and whole blood. Patients and controls have equivalent patterns of IRAK1 phosphorylation and degradation as well as IKB $\alpha$ degradation upon stimulation with IL$1 \beta$.

Conclusion Patients with MECP2/IRAK1 duplication syndrome do not show increased canonical NF- $\mathrm{KB}$ signaling in immortalized fibroblasts, PBMCs and whole blood. Therefore, we assume that these patients do not benefit from a therapeutic suppression of this pathway.
\end{abstract}

Word Count: 3523

Keywords: Xq28-duplication syndrome, methyl CpG binding protein 2 (MECP2) duplication syndrome, methyl CpG binding protein 2 (MECP2), interleukin-1 receptor-associated kinase 1 (IRAK1), canonical NF- $\mathrm{KB}$ signaling, inborn errors of immunity 


\section{Introduction}

Patients with duplication of methyl CpG binding protein 2 (MECP2) on chromosome Xq28 were first described in 2005 [1,2]. The clinical phenotype is characterized by developmental delay, hypotonia, epileptic seizures as well as recurrent infections [1,2]. Approximately $1 \%$ of severe X-linked intellectual disability in males might be explained by $M E C P 2$ duplication syndrome (MDS) [3]. Reviewing the literature, we identified 102 articles describing patients with duplications in Xq28 of varying size but encompassing at least the MECP2 and interleukin-1 receptor-associated kinase 1 (IRAK1) gene, 14 of them published before the initial description of MDS (Table 1). From 1987 until now, at least 545 cases with confirmed genotype were published (504 males and 41 symptomatic females) (Table 1). Additionally, the duplication was suspected in 39 related patients (Table 1). However, the numbers of patients might be underestimated regarding the unevenly distributed origin of publications (43 European, 25 North American, 23 East-Asian, 5 Rest of Asia including Russia, 3 Australian, 2 South American, 1 African) (Table 1). Most females with MECP2 duplication are unaffected carriers showing a favorably skewed X chromosome inactivation (XCI) pattern [1,4-6]. However, some females show a mild to severe phenotype. The main hypotheses are that symptoms in females might, on the one hand, be caused by the location of the duplicated material into an autosome or on the other hand, by an unfavorable skewed X chromosome inactivation (XCI) [7-20]. However, the extent of the symptoms in females with MECP2 duplication cannot be correlated with their XCI pattern, at least as assessed in peripheral blood [21].

Seventy-eight percent of reported patients (376/479) suffer from recurrent or severe infections (Table 1). Most common are respiratory infections with $98 \%$ of reported cases (316/324) but patients also present with otitis media, urinary tract infections and sepsis (Table 1). Early death (defined as <25 years) is reported with a frequency of 4 to $55 \%$ [1,22-24]. Among the 67 patients with described cause of early death, $58(87 \%)$ died in the context of a severe infection at the age of 3 weeks to 24 years (median 11 years; data available for 43 patients only) [1,2,5-7,9,12,22-48]. Eighty-two percent (328/398) of males suffer from recurrent or severe infections but only $61 \%$ (20/33) of the described females. Few studies further examined the detailed infectious and the underlying immunological phenotype of the patients. In contrast to the wide-spread notion of "recurrent severe infections", information about identified pathogens is only available for 19 patients [7,12,16,33,40,49,50]. Among the 55 isolated pathogens were 45 bacteria (most of all $S$. pneumoniae, H. influenzae, E. coli and $S$. aureus), 6 viruses and 4 Candida (Table S1). However, as the total viable counts are not stated it remains unclear if these were the diseasecausing pathogens. Bronchoalveolar lavage for the identification of pathogens was only performed in 7 patients [40,50].

Few studies have examined patients for their immunological phenotype [29,31,40,49,51]. The most common characteristic is a poor response to vaccination especially against Streptococcus pneumoniae which was described in 15/26 patients [29,31,40]. Some patients show selective deficiency of immunoglobulin (Ig) A (11/47) and/ or IgG2 (7/24) [26,27,29,31,35,36,39,40,49,51-54]. Moreover, several patients present with episodes of unexplained fever and remarkably high C-reactive protein (CRP) values during non-invasive infections [32,33,38,40,50,55]. In 2015, Bauer et al. suggested the substitution of polyvalent IgG in patients with an IgG2-subclass deficiency and/or low post-vaccination titers against pneumococci who suffer from recurrent infections - eventually combined with prophylactic antibiotics [40,50]. In the 26 studies published since 2016, only three evaluated the immunoglobulin levels and none mentioned the response to vaccination $[49,51,56]$. Four patients were mentioned to receive antibiotic prophylaxis $[46,49,50]$. As infections still limit the quality of life and are the most common cause of death in MDS patients, there seems to be an unmet clinical need regarding pneumological and microbiological diagnostics as well as targeted anti-infectious treatment [23].

It remains unknown, whether recurrent fever and strong acute-phase response in these patients are rather driven by infections which are difficult to clear, and/ or by autoinflammation. Both hypotheses, the one of an "infectious fever" and the one of an "autoinflammatory fever" are not mutually exclusive [27,57-59]. In 2009, Kirk et al. suspected a link between IRAK1 duplication and susceptibility to infection [32]. IRAK1 participates in multiple IL-1 and TLR-driven signaling processes that regulate immunity and inflammation [60-66]. For instance, IRAK1 plays an important role in the regulation of both, the interleukin 1 (IL-1)-mediated and the Toll-like receptor (TLR)-mediated, so-called canonical signaling pathway of NFКB (nuclear factor 'kappa-light-chain-enhancer' of activated B-cells) (Fig. 1). Upon binding, IL-1 receptors with their respective cytokine or TLR with their respective ligand, these receptors recruit the adaptor protein myeloid differentiation primary response 88 (MyD88) which associates with IRAK4 via a homophilic interaction between their death domains. IRAK4 induces the phosphorylation of IRAK1. The hyperphosphorylated IRAK1 then dissociates from the complex and associates with TNF receptor-associated factor 6 (TRAF6) to activate TAK-1/TAB (TGF- $\beta$ - activated kinase/TAK1-binding proteins). The latter enhances the activity of the I $\kappa \mathrm{B}$ kinase (IKK) complex, which in turn leads to phosphorylation and

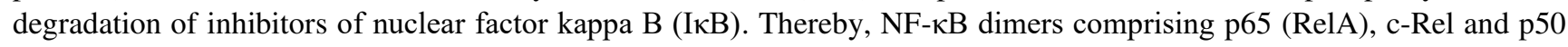
are activated and migrate into the nucleus which results in gene transcription and the induction of inflammatory cytokines such as tumor necrosis factor $\alpha(\mathrm{TNF}-\alpha)$, IL-1 $\beta$, IL-6 and IL-12 [60-66]. 
Della Mina et al. examined the canonical NF- $\kappa \mathrm{B}$ signaling in an IRAK1-null patient [67]. The patient's fibroblasts showed poor responses upon stimulation with TLR2/6- and TLR4-agonists but unimpaired responses to IL-1 $\beta$. The patient's peripheral blood mononuclear cells (PBMCs) responded normally to IL-1 $\beta$ as well as TLR2/6- and TLR4-agonists [67]. Responses to TLR3-agonist Poly(I:C) were not influenced as it signals via a TRIF-dependent pathways [67].

The combination of the clinical phenotype in MDS and the duplication of the IRAK1 gene brings up the question if IRAK1 overexpression causes increased canonical NF- $\kappa \mathrm{B}$ signaling and detrimentally increased acute phase responses. Considering the results of Della Mina et al. we hypothesized that patients with MECP2/IRAK1 duplication might show enhanced cytokine production in fibroblasts upon simulation with TLR2/6- and TLR4-agonists. Therefore, we evaluated the production of proinflammatory cytokines as well as the I $\kappa \mathrm{B} \alpha$-degradation and IRAK1 phosphorylation upon stimulation with IL-1 $\beta$ and TLR-agonists in SV40 immortalized fibroblasts of 9 patients with MECP2/IRAK1 duplication syndrome, respectively. Additionally, we investigated the production of proinflammatory cytokines not only in PBMCs but also whole blood. 


\section{Methods}

\section{Patients}

The study was conducted in accordance with the ethical standards of the 1964 Helsinki declaration and the institutional research committee (Charité-Universitätsmedizin Berlin, Germany, EA2/063/12). Informed consent was obtained from each patient or the patients' parents. Our cohort consists of 9 male patients diagnosed with MDS. We recruited them by contacting patients who participated as well as physicians who cooperated in our previous study [40]. Five of the patients were described before [40,50,68]. A duplication of at least MECP2 and IRAKI was confirmed in all patients enrolled by array-based Comparative Genomic Hybridization (array-CGH) prior to this study. We standardized the ranges of the duplications to Genome Reference Consortium Human Build 37 (GRCh37) by the NCBI Genome Remapping Service to compare the duplication size of all patients.

\section{Material}

Fibroblasts of P1, P2, P3 and P4 as well as of 4 healthy individuals were obtained by skin biopsies and immortalized by simian virus (SV40) as described previously [40,69]. Blood samples of P3, P5, P6, P7, P8 and P9 as well as of healthy controls were acquired in parallel to routine blood tests. As P1 and P2 deceased, and we were not able to contact P4 recently, we were not able to obtain currant blood samples from P1, P2 and P4. P5-9 did not donate fibroblasts. We isolated the PBMCs and performed the analysis in our laboratory with the same methods and equipment.

\section{Cell Stimulation and Cytokine Determination (ELISA)}

Levels of IL-6 and IL-8 production were assessed in SV40-fibroblasts of P1, P2, P3 and P4 as well as of healthy controls incubated for 24 hours in the presence of IL-1 $\beta$ (0,1 ng/ml, R\&D Systems), TNF- $\alpha$ (20 ng/ml, R\&D Systems), Phorbol-12Myristat-13-Acetat (PMA)/Ionomycin $\left(1 \times 10^{-7} \mathrm{M} / 1 \times 10^{-5} \mathrm{M}\right.$, Sigma-Aldrich) or TLR-agonists (TLR4-agonist LPS (10 $\mu \mathrm{g} / \mathrm{ml}$, Sigma-Aldrich), TLR2/6-agonist $\mathrm{PAM}_{2} \mathrm{CSK}_{4}(10 \mu \mathrm{g} / \mathrm{ml}$, Invivogen) or TLR3-agonist Poly(I:C) (25 $\mu \mathrm{g} / \mathrm{ml}$, Invivogen)), as well as in PBMCs of P3, P5, P6, P7, P8 and P9 as well as of healthy controls incubated for 48 hours in the presence of IL-1 $\beta$ ( $1 \mathrm{ng} / \mathrm{ml}$, R\&D Systems), TNF- $\alpha$ (20 ng/ml, R\&D Systems), PMA/Ionomycin $\left(1 \times 10^{-7} \mathrm{M} / 1 \times 10^{-5} \mathrm{M}\right.$, Sigma-Aldrich) or TLR-agonists (TLR4-agonist LPS (1 ng/ml, Sigma-Aldrich) or TLR2/6-agonist $\mathrm{PAM}_{2} \mathrm{CSK}_{4}(1 \mu \mathrm{g} / \mathrm{ml}$, Invivogen)). Cytokine concentrations in cell culture supernatants were assessed by Enzyme-linked Immunosorbent Assay (ELISA) using "PeliPair reagent" sets (Sanquin) for human IL-6 and IL-8 according to the manufacturer's protocol.

IL-6 and IL-10 levels were measured in heparinized whole blood of P3, P5, P6, P7, P8 and P9 incubated for 48 hours in the presence of IL-1 $\beta$ (20 ng/ml, R\&D Systems), TNF- $\alpha$ (20 ng/ml, R\&D Systems), PMA/Ionomycin (1x10 ${ }^{-7} \mathrm{M} / 1 \times 10^{-5} \mathrm{M}$, Sigma-Aldrich) or TLR-agonists (TLR4-agonist LPS (1 ng/ml, Sigma-Aldrich) or TLR2/6-agonist PAM CSK $_{4}(100$ ng/ml, Invivogen)). The cytokine concentrations were measured by ECLIA by Labor Berlin on an IMMULITE® 1000 (Siemens) and compared to a cohort of healthy controls assessed in our laboratory $(n=179)$ [70].

\section{Western Blots}

To analyze IRAK1-expression and I $\kappa \mathrm{B} \alpha$-degradation, we stimulated SV40-immortalized fibroblasts of P1, P2, P3 and P4 as well as of healthy controls with IL-1 $\beta$ (10 ng/ml, R\&D Systems), TLR4-agonist lipopolysaccharide (LPS) (10 $\mu \mathrm{g} / \mathrm{ml}, \mathrm{Sigma}-$ Aldrich) and TNF- $\alpha$ (20 ng/ml, R\&D Systems) for 5, 15, 30, 45, 60 and 90 minutes as well as 20, 60,120 and 240 minutes, respectively. The further steps were performed as described previously using the following antibodies: IкBa (sc-371, Santa Cruz Biotechnology), IRAK1 (sc-7883, Santa Cruz Biotechnology), IRAK-4 (ADI-KAP-ST206-E, Enzo), Glycerinaldehyd3-phosphat-Dehydrogenase (GAPDH) (sc-25778, Santa Cruz Biotechnology), P38 MAPK (9212S, Cell Signaling), Goat Anti Rabbit IgG (111-035-045, Dianova) [70]. Detailed protocols are available upon request. 


\section{Results}

\section{Patients with MECP2/IRAK1 duplication suffer from recurrent respiratory infections}

Our 9 patients show duplications of variable size at least encompassing the neighboring genes MECP2 and IRAK1 (Fig. 2). All patients suffered from recurrent or severe infections, mostly respiratory infections, which often required hospitalization.

Patient 3 is a 25-year-old patient who is followed-up in our department at least 4 times a year and was clinically and molecularly characterized before [P1 in 40,50]. Array comparative genome hybridization (array-CGH) confirmed a duplication of $1.1 \mathrm{Mb}$ at Xq28. He first presented with global developmental delay, muscular hypotonia and spastic tetra paresis. He suffers from epilepsy and recurrent severe infections. Of his in total 64 episodes of pneumonia, he had developed 47 until his $14^{\text {th }} \mathrm{y} / \mathrm{a}$. After starting an immunoglobulin substitution (at $12 \mathrm{y} / \mathrm{a}$ ) as well as supportive measures and antibiotic prophylaxis (at $14 \mathrm{y} / \mathrm{a}$ ), the frequency of infections declined, leading to 3 episodes of pneumonia only in the following 8 years. Despite this treatment, we recorded an increase of hospital admissions due to infections in the last 2 years including 12 episodes of pneumonia and 2 episodes of sepsis (Fig. S1). Throughout the last years, the boy developed chronic aspiration and shows bronchiectasis in his latest CT scans (Fig. S2). We are now detecting opportunistic pathogens such as a multidrugresistant Citrobacter freundii as well as Candida glabrata and Trichosporon asahii in bronchoalveolar lavages. He is currently under prophylactic anti-infective treatment with Cotrimoxazole, Penicillin and Fluconazole. The boy shows a normal total immunoglobulin titer but deficiency of $\operatorname{IgG} 2$, IgG4, IgA and $\operatorname{IgM}$. A polysaccharide-specific antibody deficiency persisted despite repeated vaccinations.

The baseline clinical features of all patients in our cohort are summarized in Table 2. Detailed case reports of P1, P2 and P49 are described in the Online Supplementary Electronic Material.

\section{IRAK1 duplication leads to increased protein levels in patient-derived fibroblast cell lines}

First, we characterized the SV40-immortalized fibroblasts cell lines of both patients and healthy controls for their expression of IRAK1, IRAK4 and GAPDH (Fig. 3). We used an IRAKI-deficient and an IRAK4-deficient cell line as negative controls. The patients' cells (P1-P4) contained at least twice as much IRAK1 as the cells of the healthy controls (C1-C4) (Fig. 3). The calculated ratios are stated in the Online Supplementary Electronic Material.

\section{IRAK1 duplication does neither promote excessive cytokine production in fibroblasts nor in PBMC, nor in whole blood}

We hypothesized that the susceptibility to infection could be caused by a hyperinflammatory immune response due to increased canonical NF- $\kappa \mathrm{B}$ signaling because of IRAK1 overexpression. Therefore, we determined the impact of the $M E C P 2$ and IRAKI duplication on the canonical NF- $\mathrm{BB}$ signaling. Hence, we performed an ELISA to measure the cytokine production in the cell culture supernatants of SV40 immortalized fibroblasts, PBMCs and whole blood upon stimulation with IL-1 $\beta$ as well as the TLR-agonists LPS (TLR4), PAM ${ }_{2}$ CSK $_{4}$ (TLR2/6) and Poly(I:C) (TLR3). We used TNF- $\alpha$ and PMA/Ionomycin as NF- $\kappa \mathrm{B}$-independent intraassay controls. Production of IL-6 and IL-8 upon stimulation with IL-1 $\beta$ or TLR4/2/6-agonists was increased in fibroblasts of both, healthy controls and MECP2/IRAK1-duplicated patients, but we did not see a difference between the two groups (Fig. 4a and 4b). Especially, we did not see an enhanced response upon stimulation with TLR4-agonist LPS and TLR2/6-agonist $\mathrm{PAM}_{2} \mathrm{CSK}_{4}$ in immortalized fibroblasts of patients compared to healthy controls. In IRAK4-deficient fibroblasts, cytokine production upon stimulation with IL-1 $\beta$, TLR4-agonist LPS and TLR2/6-agonist $\mathrm{PAM}_{2} \mathrm{CSK}_{4}$ was absent (Fig. 4a and 4b). In IRAK1-deficient fibroblasts, we found a poor response to TLR4agonist LPS and TLR2/6-agonist $\mathrm{PAM}_{2} \mathrm{CSK}_{4}$ but an almost unimpaired response to IL-1 $\beta$ (Fig. 4a and 3b). All fibroblasts showed increased cytokine production upon activation with TLR3-agonist Poly(I:C), TNF- $\alpha$ and PMA/Ionomycin (Fig. 4a and $3 b)$. The response upon stimulation with IL-1 $\beta$, TLR-agonists and TNF- $\alpha$ was similar for PBMCs and whole blood in both groups (Fig. 4c-f). These results indicate that MECP2/IRAK1-duplication does not lead to a higher amount of inflammatory cytokines upon stimulation in immortalized fibroblasts, PBMCs and whole blood.

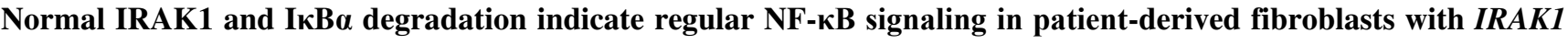 duplication}

Having observed that MECP2/IRAK1-duplication does not cause an increased acute inflammatory response in vitro we hypothesized that canonical NF- $\kappa \mathrm{B}$ signaling may be altered regarding the phosphorylation and degradation of involved proteins such as IRAK1 and $\mathrm{I} \kappa \mathrm{B} \alpha$. To further delineate this pathway, we performed western blots on whole cell lysates of SV40 fibroblasts of P1-4, a healthy control (C) as well as an IRAKI- and IRAK4-deficient control stimulated with IL-1 $\beta$, LPS and TNF- $\alpha$. Upon activation, IRAK1 is phosphorylated leading to a higher mass. Phosphorylated IRAK1 becomes hence visible as a smear above the band of non-phosphorylated IRAK1. Both, the patients' and the control's cells showed a 
similar pattern of IRAK1 phosphorylation and degradation upon activation with IL-1 $\beta$ whereas it was absent in IRAK4deficient fibroblasts (Fig. 5a). Self-explanatory, the IRAK1-deficient fibroblasts did not contain any IRAK1 protein and therefore it could not be phosphorylated or degraded (Fig. 5a). IRAK1 phosphorylation and degradation could not be induced by LPS or TNF- $\alpha$ stimulation in any of the cells (Fig. 5a). The time pattern of I $\mathrm{BB} \alpha$ degradation upon IL-1 $\beta$ stimulation and the reoccurrence of non-phosphorylated I $\mathrm{B} \alpha$ was similar in cells of the patient and the control tested (Fig. 5b). Overall, our data suggests that there is no difference in the activity of the canonical NF- $\mathrm{B}$ signaling in MECP2/IRAK1-duplicated patients.

\section{Discussion}

Although research on $M E C P 2 / I R A K 1$ duplication syndrome has increased, a comprehensive pathophysiological mechanism that explains the frequency and severity of infections, the most common cause of death, remains unknown. Numerous publications describe patients who repeatedly require hospitalization, invasive ventilation and intensive care admission [36,39,40,50,56]. In P3, pneumococcal immunization and antibiotic prophylaxis reduced the number of infections per year drastically for many years (Fig. S1). However, after successful long-term prophylaxis on antibiotics and IgG he has been presenting multiple times with pneumonia caused by multidrug-resistant and rare pathogens since the age of 23 . Patients like these show that the control of infections clearly is still an unmet clinical need.

IRAK1 participates in multiple IL-1 and TLR-driven signaling processes that regulate immunity and inflammation [60-65]. Therefore, we hypothesized that the infections may be triggered by a strong acute phase response due to IRAK1 overexpression and subsequently increased canonical NF- $\mathrm{BB}$ signaling. However, in our cohort we did not see any evidence of increased IRAK1-dependent degradation of I $\mathrm{B}$ - $\alpha$. We demonstrated that the production of proinflammatory cytokines IL-6 and IL-8 upon stimulation with IL-1 $\beta$ and TLR-agonists is similar in immortalized fibroblasts as well as PBMCs and whole blood of patients with MECP2/IRAK1 duplication and healthy controls. Especially, we did not see an enhanced response upon stimulation with TLR4-agonist LPS and TLR2/6-agonist $\mathrm{PAM}_{2} \mathrm{CSK}_{4}$ in immortalized fibroblasts. The results in our healthy controls as well as our IRAKI- and IRAK4-deficient controls were similar to the results of Della Mina et al. [67]. Response to IL-1 $\beta$ and TLR-agonists seems to be normal not only in PBMCs but also whole blood which suggests that canonical NF- $\kappa \mathrm{B}$ signaling is also neither increased nor impaired in neutrophilic granulocytes of patients with MECP2/IRAK1 duplication.

This raises the question of whether the inflammation observed in MDS patients might rather be driven by an infectious than an autoinflammatory process. $91 \%(411 / 454)$ of the published patients suffered from muscle hypotonia suggesting that an insufficient occlusion of the gastric sphincter, as well as swallowing difficulties, could favor aspiration (Table 1). Gastroesophageal reflux with subsequent aspiration was suggested as a cause for frequent respiratory tract infections [27,58]. However, only 55\% (149/270) of the patients were described to suffer from reflux whereas 78\% of the patients (376/479) were described to suffer from recurrent or severe infections $([3,5,6,9,15,18,23,24,26,27,29,30,33-$ $35,37,39,42,46,47,49,56,58,71-76]$, Table 1$)$.

The NF- $\mathrm{BB}$ signaling in fibroblasts and blood seems to be unimpaired. However, this might be different in other tissues such as lung epithelia. On the one hand, IRAK-1 was shown to be essential for IL-8 production in human airway epithelial cells [77]. On the other hand, IRAK-1 is necessary for the rhinovirus-stimulated induction of CXCL-10 in airway epithelial cells and macrophages [78]. Both excessive production of IL-8 and CXCL-10 could contribute to lung inflammation leading to the clinical phenotype of MDS patients. From a scientific point of view, it seems interesting to study the cytokine production and CXCL-10 induction in airway epithelial cells of patients with MECP2/IRAK1 duplication. However, it seems almost impossible to obtain sufficient amounts of primary lung tissue from children with such a rare disease in a standardized way, let alone enough to culture lung epithelia. An alternative strategy to investigate the role of IRAK1 in lung epithelia might be to differentiate human induced pluripotent stem cells (hiPSCs) to lung epithelial cells [79].

Yang et al. proposed that severe infections in MDS patients occur due to the lack of TH1 response and subsequently low IFN- $\gamma$ activity [57]. However, a generally impaired IFN- $\gamma$ secretion could not be reproduced by Bauer et al. [40]. Furthermore, complete IFN- $\gamma$ deficiency is characterized by a selective predisposition to infections caused by mycobacteria, Salmonella, or Candida species [80,81]. This does not correlate with the clinical phenotype of MDS patients who typically show purulent bronchitis caused by bacteria which are capable of building a capsule such as Streptococcus pneumoniae or Haemophilus influenzae [40]. In the so far published cases of MDS, an infection with mycobacteria was only described once [40].

Besides its role for canonical NF- $\kappa$ B signaling, IRAK1 controls the induction of interferons via Interferon Regulatory Factor 7 (IRF7) $[61,63,66]$. In human IRF7 deficiency, children are selectively susceptible to severe influenza and show an impaired 
type I IFN signature [82]. In vitro, IRAK-1 regulates the transcriptional activation of IRF7 by directly binding and phosphorylating it. TLR7- and TLR9-mediated IFN $\alpha$-production is abolished in IRAK1-deficient mice, whereas inflammatory cytokine production is not impaired [63]. This brings up the question whether duplication of the IRAK1 gene and thus IRAK1 overexpression causes an increased activation of the TLR7- and TLR9-mediated interferon- $\alpha$ induction pathway leading to an increased release of interferons and consequently to a hyperinflammatory immune response. However, CD169 expression on monocytes, which is correlated with systemic type I IFN levels, was normal in P3 both, while he suffered from an infection and when he was free of infections [83,84]. Further, MECP2 overexpressing mice had been described as particular susceptible for severe influenza A infection. During infection, they show neutrophilia, increased cytokine production, excessive corticosterone levels, defective adaptive immunity, and vascular pathology. This raises the question if the inflammation-underlying pathomechanism in humans suffering from $M E C P 2$ duplication syndrome is rather caused by the overexpression of MECP2 than the overexpression of IRAK1 [59]. In a humanized mouse model of MDS, intracerebroventricular antisense oligonucleotide (ASO) therapy was shown to decrease MECP2 expression in the brain and to reduce behavioral deficits as well as to restore/correct reduced IFN- $\gamma$ mRNA levels in the blood [85]. If inflammation in MDS is rather caused by the duplication of MECP2 itself, than by duplication of IRAK1, ASO against MECP2 might be a feasible treatment option for these patients. The effects of such ASO therapy, applied in compartments such as blood and lungs, may also warrant further investigation.

In summary, patients with $M E C P 2$ duplication syndrome do not show increased canonical NF- $\mathrm{B}$ signaling in whole blood, PBMCs or SV40 immortalized fibroblasts. Therefore, we assume that these patients do not benefit from a therapeutic suppression of this pathway. 


\section{Statements \& Declarations}

\section{Funding}

The authors declare that no funds, grants, or other support were received during the preparation of this manuscript.

\section{Competing Interests}

The authors have no relevant financial or non-financial interests to disclose.

\section{Author Contributions}

I.G. designed this study, planned and performed experiments, analyzed results, interpreted the data and wrote the manuscript. U.K. provided reagents, performed experiments, and analyzed results. D.L.W., J.K. and S.M. provided reagents and supported experiments. R.K., A.J., R.R., S.E. and H.V.E. took care of patients and provided patient material. A.P. and J.L.C. provided the IRAKIy/- and IRAK4-/- cell lines. H.v.B. designed and led the study, took care of patients, provided patient material, planned experiments, analyzed results, interpreted data and edited the manuscript. The first draft of the manuscript was written by I.G. and all authors commented on previous versions of the manuscript. All authors read and approved the manuscript in its final form.

\section{Data Availability}

The datasets generated during the current study are available from the corresponding author on reasonable request.

\section{Ethics approval}

The study was conducted in accordance with the ethical standards of the 1964 Helsinki declaration and the institutional research committee (Charité-Universitätsmedizin Berlin, Germany, EA2/063/12).

\section{Consent to participate}

Informed consent was obtained from the parents of all individual participants included in the study.

\section{Consent to publish}

The authors affirm that human research participants' legal guardians provided informed consent for publication of the data of their children. 


\section{References}

[1] Van Esch H, Bauters M, Ignatius J, Jansen M, Raynaud M, Hollanders K, et al. Duplication of the MECP2 region is a frequent cause of severe mental retardation and progressive neurological symptoms in males. Am J Hum Genet 2005;77:442-53. https://doi.org/10.1086/444549.

[2] Meins M, Lehmann J, Gerresheim F, Herchenbach J, Hagedorn M, Hameister K, et al. Submicroscopic duplication in Xq28 causes increased expression of the MECP2 gene in a boy with severe mental retardation and features of Rett syndrome. J Med Genet 2005;42:e12. https://doi.org/10.1136/jmg.2004.023804.

[3] Ramocki MB, Tavyev YJ, Peters SU. The MECP2 duplication syndrome. Am J Med Genet A 2010;152A:1079-88. https://doi.org/10.1002/ajmg.a.33184.

[4] del Gaudio D, Fang P, Scaglia F, Ward PA, Craigen WJ, Glaze DG, et al. Increased MECP2 gene copy number as the result of genomic duplication in neurodevelopmentally delayed males. Genet Med Off J Am Coll Med Genet 2006;8:784-92. https://doi.org/10.1097/01.gim.0000250502.28516.3c.

[5] Clayton-Smith J, Walters S, Hobson E, Burkitt-Wright E, Smith R, Toutain A, et al. Xq28 duplication presenting with intestinal and bladder dysfunction and a distinctive facial appearance. Eur J Hum Genet EJHG 2009;17:434-43. https://doi.org/10.1038/ejhg.2008.192.

[6] Lugtenberg D, Kleefstra T, Oudakker AR, Nillesen WM, Yntema HG, Tzschach A, et al. Structural variation in Xq28: MECP2 duplications in $1 \%$ of patients with unexplained XLMR and in $2 \%$ of male patients with severe encephalopathy. Eur J Hum Genet EJHG 2009;17:444-53. https://doi.org/10.1038/ejhg.2008.208.

[7] Bialer M. De novo trisomy Xq28-qter detected by subtelomeric FISH screening. Am J Hum Genet 2003.

[8] Lachlan KL, Collinson MN, Sandford ROC, van Zyl B, Jacobs PA, Thomas NS. Functional disomy resulting from duplications of distal Xq in four unrelated patients. Hum Genet 2004;115:399-408.

https://doi.org/10.1007/s00439-004-1175-x.

[9] Sanlaville D, Prieur M, de Blois M-C, Genevieve D, Lapierre J-M, Ozilou C, et al. Functional disomy of the Xq28 chromosome region. Eur J Hum Genet EJHG 2005;13:579-85. https://doi.org/10.1038/sj.ejhg.5201384.

[10] Auber B, Burfeind P, Thiels C, Alsat EA, Shoukier M, Liehr T, et al. An unbalanced translocation resulting in a duplication of Xq28 causes a Rett syndrome-like phenotype in a female patient. Clin Genet 2010;77:593-7. https://doi.org/10.1111/j.1399-0004.2009.01363.x.

[11] Makrythanasis P, Moix I, Gimelli S, Fluss J, Aliferis K, Antonarakis SE, et al. De novo duplication of MECP2 in a girl with mental retardation and no obvious dysmorphic features. Clin Genet 2010;78:175-80. https://doi.org/10.1111/j.1399-0004.2010.01371.x.

[12] Reardon W, Donoghue V, Murphy A-M, King MD, Mayne PD, Horn N, et al. Progressive cerebellar degenerative changes in the severe mental retardation syndrome caused by duplication of MECP2 and adjacent loci on Xq28. Eur J Pediatr 2010;169:941-9. https://doi.org/10.1007/s00431-010-1144-4.

[13] Mayo S, Monfort S, Roselló M, Orellana C, Oltra S, Armstrong J, et al. De novo interstitial triplication of MECP2 in a girl with neurodevelopmental disorder and random X chromosome inactivation. Cytogenet Genome Res 2011;135:93-101. https://doi.org/10.1159/000330917.

[14] Grasshoff U, Bonin M, Goehring I, Ekici A, Dufke A, Cremer K, et al. De novo MECP2 duplication in two females with random X-inactivation and moderate mental retardation. Eur J Hum Genet EJHG 2011;19:507-12. https://doi.org/10.1038/ejhg.2010.226.

[15] Bijlsma EK, Collins A, Papa FT, Tejada MI, Wheeler P, Peeters E a. J, et al. Xq28 duplications including MECP2 in five females: Expanding the phenotype to severe mental retardation. Eur J Med Genet 2012;55:404-13. https://doi.org/10.1016/j.ejmg.2012.02.009.

[16] Shimada S, Okamoto N, Hirasawa K, Yoshii K, Tani Y, Sugawara M, et al. Clinical manifestations of Xq28 functional disomy involving MECP2 in one female and two male patients. Am J Med Genet A 2013;161A:1779-85. https://doi.org/10.1002/ajmg.a.35975.

[17] Scott Schwoerer J, Laffin J, Haun J, Raca G, Friez MJ, Giampietro PF. MECP2 duplication: possible cause of severe phenotype in females. Am J Med Genet A 2014;164A:1029-34. https://doi.org/10.1002/ajmg.a.36380.

[18] Fieremans N, Bauters M, Belet S, Verbeeck J, Jansen AC, Seneca S, et al. De novo MECP2 duplications in two females with intellectual disability and unfavorable complete skewed X-inactivation. Hum Genet 2014;133:135967. https://doi.org/10.1007/s00439-014-1469-6.

[19] Novara F, Simonati A, Sicca F, Battini R, Fiori S, Contaldo A, et al. MECP2 duplication phenotype in symptomatic females: report of three further cases. Mol Cytogenet 2014;7:10. https://doi.org/10.1186/1755-8166-7-10.

[20] San Antonio-Arce V, Fenollar-Cortés M, Oancea Ionescu R, DeSantos-Moreno T, Gallego-Merlo J, Illana Cámara FJ, et al. MECP2 Duplications in Symptomatic Females: Report on 3 Patients Showing the Broad Phenotypic Spectrum. Child Neurol Open 2016;3:2329048X16630673. https://doi.org/10.1177/2329048X16630673. 
[21] El Chehadeh S, Touraine R, Prieur F, Reardon W, Bienvenu T, Chantot-Bastaraud S, et al. Xq28 duplication including MECP2 in six unreported affected females: what can we learn for diagnosis and genetic counselling? Clin Genet 2017;91:576-88. https://doi.org/10.1111/cge.12898.

[22] Van Esch H. MECP2 Duplication Syndrome. Mol Syndromol 2012;2:128-36. https://doi.org/10.1159/000329580.

[23] Miguet M, Faivre L, Amiel J, Nizon M, Touraine R, Prieur F, et al. Further delineation of the MECP2 duplication syndrome phenotype in 59 French male patients, with a particular focus on morphological and neurological features. J Med Genet 2018;55:359-71. https://doi.org/10.1136/jmedgenet-2017-104956.

[24] Peters SU, Fu C, Suter B, Marsh E, Benke TA, Skinner SA, et al. Characterizing the phenotypic effect of Xq28 duplication size in MECP2 duplication syndrome. Clin Genet 2019;95:575-81. https://doi.org/10.1111/cge.13521.

[25] Vasquez Al, Rivera H, Bobadilla L, Crolla JA. A familial Xp+ chromosome, dup (Xq26.3-->qter). J Med Genet 1995;32:891-3. https://doi.org/10.1136/jmg.32.11.891.

[26] Pai GS, Hane B, Joseph M, Nelson R, Hammond LS, Arena JF, et al. A new X linked recessive syndrome of mental retardation and mild dysmorphism maps to Xq28. J Med Genet 1997;34:529-34. https://doi.org/10.1136/jmg.34.7.529.

[27] Lubs H, Abidi F, Bier J-AB, Abuelo D, Ouzts L, Voeller K, et al. XLMR syndrome characterized by multiple respiratory infections, hypertelorism, severe CNS deterioration and early death localizes to distal Xq28. Am J Med Genet 1999;85:243-8. https://doi.org/10.1002/(SICI)1096-8628(19990730)85:3<243::AID-AJMG11>3.0.CO;2-E.

[28] Teek R ÕK. Case report: boy with severe hypotonia, hypogenitalism, chronic interstitial pneumonia, and partial $X$ disomy, karyotype 46,X,der(Y)t(X;Y)(q28;q11.2). Eur J Hum Genet 2004.

[29] Friez MJ, Jones JR, Clarkson K, Lubs H, Abuelo D, Bier J-AB, et al. Recurrent Infections, Hypotonia, and Mental Retardation Caused by Duplication of MECP2 and Adjacent Region in Xq28. Pediatrics 2006;118:e1687-95. https://doi.org/10.1542/peds.2006-0395.

[30] Smyk M, Obersztyn E, Nowakowska B, Nawara M, Cheung SW, Mazurczak T, et al. Different-sized duplications of Xq28, including MECP2, in three males with mental retardation, absent or delayed speech, and recurrent infections. Am J Med Genet Part B Neuropsychiatr Genet Off Publ Int Soc Psychiatr Genet 2008;147B:799-806. https://doi.org/10.1002/ajmg.b.30683.

[31] Prescott TE, Rødningen OK, Bjørnstad A, Stray-Pedersen A. Two brothers with a microduplication including the MECP2 gene: rapid head growth in infancy and resolution of susceptibility to infection. Clin Dysmorphol 2009;18:78-82. https://doi.org/10.1097/MCD.0b013e32831e19cd.

[32] Kirk EP, Malaty-Brevaud V, Martini N, Lacoste C, Levy N, Maclean K, et al. The clinical variability of the MECP2 duplication syndrome: description of two families with duplications excluding L1CAM and FLNA. Clin Genet 2009;75:301-3. https://doi.org/10.1111/j.1399-0004.2008.01102.x.

[33] Carvalho CMB, Ramocki MB, Pehlivan D, Franco LM, Gonzaga-Jauregui C, Fang P, et al. Inverted genomic segments and complex triplication rearrangements are mediated by inverted repeats in the human genome. Nat Genet 2011;43:1074-81. https://doi.org/10.1038/ng.944.

[34] Honda S, Hayashi S, Nakane T, Imoto I, Kurosawa K, Mizuno S, et al. The incidence of hypoplasia of the corpus callosum in patients with dup $(X)(q 28)$ involving MECP2 is associated with the location of distal breakpoints. Am J Med Genet A 2012;158A:1292-303. https://doi.org/10.1002/ajmg.a.35321.

[35] Honda S, Satomura S, Hayashi S, Imoto I, Nakagawa E, Goto Y, et al. Concomitant microduplications of MECP2 and ATRX in male patients with severe mental retardation. J Hum Genet 2012;57:73-7. https://doi.org/10.1038/jhg.2011.131.

[36] Tang SS, Fernandez D, Lazarou LP, Singh R, Fallon P. MECP2 triplication in 3 brothers - a rarely described cause of familial neurological regression in boys. Eur J Paediatr Neurol EJPN Off J Eur Paediatr Neurol Soc 2012;16:209-12. https://doi.org/10.1016/j.ejpn.2011.07.011.

[37] Shimada S, Okamoto N, Ito M, Arai Y, Momosaki K, Togawa M, et al. MECP2 duplication syndrome in both genders. Brain Dev 2013;35:411-9. https://doi.org/10.1016/j.braindev.2012.07.010.

[38] Fukushi D, Yamada K, Nomura N, Naiki M, Kimura R, Yamada Y, et al. Clinical characterization and identification of duplication breakpoints in a Japanese family with Xq28 duplication syndrome including MECP2. Am J Med Genet A 2014;164A:924-33. https://doi.org/10.1002/ajmg.a.36373.

[39] Chow C, H M Lai A. Cytogenomic Delineation and Clinical Characterization of Three Cases of MECP2 Duplication Syndrome. J Clin Med Genomics 2015;3. https://doi.org/10.4172/2472-128X.1000125.

[40] Bauer M, Kölsch U, Krüger R, Unterwalder N, Hameister K, Kaiser FM, et al. Infectious and immunologic phenotype of MECP2 duplication syndrome. J Clin Immunol 2015;35:168-81. https://doi.org/10.1007/s10875-015-0129-5.

[41] Yi Z, Pan H, Li L, Wu H, Wang S, Ma Y, et al. Chromosome Xq28 duplication encompassing MECP2: Clinical and molecular analysis of 16 new patients from 10 families in China. Eur J Med Genet 2016;59:347-53. https://doi.org/10.1016/j.ejmg.2016.05.004.

[42] Trobaugh-Lotrario A, Martin J, López-Terrada D. Hepatoblastoma in a male with MECP2 duplication syndrome. Am J Med Genet A 2016;170:790-1. https://doi.org/10.1002/ajmg.a.37474. 
[43] Moirangthem A, Tuteja Bhatia M, Srivastava P, Mandal K, Rai A, Phadke SR. Expansion of the phenotypic spectrum in three families of methyl CpG-binding protein 2 duplication syndrome. Clin Dysmorphol 2017;26:73-7. https://doi.org/10.1097/MCD.0000000000000171.

[44] Tsuji-Hosokawa A, Matsuda N, Kurosawa K, Kashimada K, Morio T. A Case of MECP2 Duplication Syndrome with Gonadotropin-Dependent Precocious Puberty. Horm Res Paediatr 2017;87:271-6. https://doi.org/10.1159/000449222.

[45] Li X, Xie H, Chen Q, Yu X, Yi Z, Li E, et al. Clinical and molecular genetic characterization of familial MECP2 duplication syndrome in a Chinese family. BMC Med Genet 2017;18:131. https://doi.org/10.1186/s12881-0170486-4.

[46] Giudice-Nairn P, Downs J, Wong K, Wilson D, Ta D, Gattas M, et al. The incidence, prevalence and clinical features of MECP2 duplication syndrome in Australian children. J Paediatr Child Health 2019;55:1315-22. https://doi.org/10.1111/jpc.14399.

[47] Pascual-Alonso A, Blasco L, Vidal S, Gean E, Rubio P, O'Callaghan M, et al. Molecular characterization of Spanish patients with MECP2 duplication syndrome. Clin Genet 2020;97:610-20. https://doi.org/10.1111/cge.13718.

[48] Tekendo-Ngongang C, Dahoun S, Nguefack S, Moix I, Gimelli S, Zambo H, et al. MECP2 duplication syndrome in a patient from Cameroon. Am J Med Genet A 2020;182:619-22. https://doi.org/10.1002/ajmg.a.61510.

[49] van Baelen A, Verhoustraeten L, Kenis S, Meuwissen M, Boudewyns A, van Hoorenbeeck K, et al. Sleep-disordered breathing and nocturnal hypoventilation in children with the MECP2 duplication syndrome: A case series and review of the literature. Am J Med Genet A 2020. https://doi.org/10.1002/ajmg.a.61790.

[50] Bauer M, Krüger R, Kölsch U, Unterwalder N, Meisel C, Wahn V, et al. Antibiotic Prophylaxis, Immunoglobulin Substitution and Supportive Measures Prevent Infections in MECP2 Duplication Syndrome. Pediatr Infect Dis J 2018;37:466-8. https://doi.org/10.1097/INF.0000000000001799.

[51] Yon DK, Park JE, Kim SJ, Shim SH, Chae KY. A sibship with duplication of Xq28 inherited from the mother; genomic characterization and clinical outcomes. BMC Med Genet 2017;18:30. https://doi.org/10.1186/s12881-017-0394-7.

[52] Novelli A, Bernardini L, Salpietro DC, Briuglia S, Merlino MV, Mingarelli R, et al. Disomy of distal Xq in males: Case report and overview. Am J Med Genet A 2004;128A:165-9. https://doi.org/10.1002/ajmg.a.30088.

[53] Belligni EF, Palmer RW, Hennekam RCM. MECP2 duplication in a patient with congenital central hypoventilation. Am J Med Genet A 2010;152A:1591-3. https://doi.org/10.1002/ajmg.a.33311.

[54] Bertini E, Cusmai R, de Saint Basile G, Le Deist F, Di Capua M, Gaggero DR, et al. Congenital X-linked ataxia, progressive myoclonic encephalopathy, macular degeneration and recurrent infections. Am J Med Genet 1992;43:443-51. https://doi.org/10.1002/ajmg.1320430167.

[55] Lahn BT, Ma N, Breg WR, Stratton R, Surti U, Page DC. Xq-Yq interchange resulting in supernormal X-linked gene expression in severely retarded males with 46,XYq- karyotype. Nat Genet 1994;8:243-50. https://doi.org/10.1038/ng1194-243.

[56] Takeguchi R, Takahashi S, Akaba Y, Tanaka R, Nabatame S, Kurosawa K, et al. Early diagnosis of MECP2 duplication syndrome: Insights from a nationwide survey in Japan. J Neurol Sci 2021;422:117321. https://doi.org/10.1016/j.jns.2021.117321.

[57] Yang T, Ramocki MB, Neul JL, Lu W, Roberts L, Knight J, et al. Overexpression of methyl-CpG binding protein 2 impairs T(H)1 responses. Sci Transl Med 2012;4:163ra158. https://doi.org/10.1126/scitranslmed.3004430.

[58] Kokalj-Vokac N, Marcun-Varda N, Zagorac A, Erjavec-Skerget A, Zagradisnik B, Todorovic M, et al. Subterminal deletion/duplication event in an affected male due to maternal $X$ chromosome pericentric inversion. Eur J Pediatr 2004. https://doi.org/10.1007/s00431-004-1519-5.

[59] Cronk JC, Herz J, Kim TS, Louveau A, Moser EK, Sharma AK, et al. Influenza A induces dysfunctional immunity and death in MeCP2-overexpressing mice. JCI Insight 2017;2:e88257. https://doi.org/10.1172/jci.insight.88257.

[60] Moynagh PN. The NF-kappaB pathway. J Cell Sci 2005;118:4589-92. https://doi.org/10.1242/jcs.02579.

[61] Singer JW, Fleischman A, Al-Fayoumi S, Mascarenhas JO, Yu Q, Agarwal A. Inhibition of interleukin-1 receptorassociated kinase 1 (IRAK1) as a therapeutic strategy. Oncotarget 2018;9:33416-39. https://doi.org/10.18632/oncotarget.26058.

[62] Akira S, Takeda K. Toll-like receptor signalling. Nat Rev Immunol 2004;4:499-511. https://doi.org/10.1038/nri1391.

[63] Uematsu S, Sato S, Yamamoto M, Hirotani T, Kato H, Takeshita F, et al. Interleukin-1 receptor-associated kinase-1 plays an essential role for Toll-like receptor (TLR)7- and TLR9-mediated interferon-\{alpha\} induction. J Exp Med 2005;201:915-23. https://doi.org/10.1084/jem.20042372.

[64] Jain A, Kaczanowska S, Davila E. IL-1 Receptor-Associated Kinase Signaling and Its Role in Inflammation, Cancer Progression, and Therapy Resistance. Front Immunol 2014;5:553. https://doi.org/10.3389/fimmu.2014.00553.

[65] Vidya MK, Kumar VG, Sejian V, Bagath M, Krishnan G, Bhatta R. Toll-like receptors: Significance, ligands, signaling pathways, and functions in mammals. Int Rev Immunol 2018;37:20-36. https://doi.org/10.1080/08830185.2017.1380200. 
[66] Antonczyk A, Krist B, Sajek M, Michalska A, Piaszyk-Borychowska A, Plens-Galaska M, et al. Direct Inhibition of IRFDependent Transcriptional Regulatory Mechanisms Associated With Disease. Front Immunol 2019;10.

[67] Della Mina E, Borghesi A, Zhou H, Bougarn S, Boughorbel S, Israel L, et al. Inherited human IRAK-1 deficiency selectively impairs TLR signaling in fibroblasts. Proc Natl Acad Sci U S A 2017;114:E514-23. https://doi.org/10.1073/pnas.1620139114.

[68] Nageshappa S, Carromeu C, Trujillo CA, Mesci P, Espuny-Camacho I, Pasciuto E, et al. Altered neuronal network and rescue in a human MECP2 duplication model. Mol Psychiatry 2016;21:178-88. https://doi.org/10.1038/mp.2015.128.

[69] von Bernuth H, Picard C, Jin Z, Pankla R, Xiao H, Ku C-L, et al. Pyogenic bacterial infections in humans with MyD88 deficiency. Science 2008;321:691-6. https://doi.org/10.1126/science.1158298.

[70] Heller S, Kölsch U, Magg T, Krüger R, Scheuern A, Schneider H, et al. T Cell Impairment Is Predictive for a Severe Clinical Course in NEMO Deficiency. J Clin Immunol 2020;40:421-34. https://doi.org/10.1007/s10875-019-00728-y.

[71] Goodman BK, Shaffer LG, Rutberg J, Leppert M, Harum K, Gagos S, et al. Inherited duplication Xq27-qter at Xp22.3 in severely affected males: molecular cytogenetic evaluation and clinical description in three unrelated families. Am J Med Genet 1998;80:377-84. https://doi.org/10.1002/(sici)1096-8628(19981204)80:4<377::aidajmg14>3.0.co;2-7.

[72] Breman AM, Ramocki MB, Kang S-HL, Williams M, Freedenberg D, Patel A, et al. MECP2 duplications in six patients with complex sex chromosome rearrangements. Eur J Hum Genet 2011;19:409-15. https://doi.org/10.1038/ejhg.2010.195.

[73] Sanmann JN, Bishay DL, Starr LJ, Bell CA, Pickering DL, Stevens JM, et al. Characterization of six novel patients with MECP2 duplications due to unbalanced rearrangements of the X chromosome. Am J Med Genet $A$ 2012;158A:1285-91. https://doi.org/10.1002/ajmg.a.35347.

[74] Peters SU, Hundley RJ, Wilson AK, Warren Z, Vehorn A, Carvalho CMB, et al. The Behavioral Phenotype in MECP 2 Duplication Syndrome: A Comparison With Idiopathic Autism: Behavioral Phenotype in MECP2 Duplications. Autism Res 2013;6:42-50. https://doi.org/10.1002/aur.1262.

[75] Lim Z, Downs J, Wong K, Ellaway C, Leonard H. Expanding the clinical picture of the MECP2 Duplication syndrome. Clin Genet 2017;91:557-63. https://doi.org/10.1111/cge.12814.

[76] Choi Y-LJ, Wong T-KM, Ng KKD. Anesthetic Management for a Patient With MECP2 Duplication Syndrome: A Case Report. AA Pract 2020;14:e01202. https://doi.org/10.1213/XAA.0000000000001202.

[77] Dakhama A, Al Mubarak R, Pavelka N, Voelker D, Seibold M, Ledford JG, et al. Tollip Inhibits ST2 Signaling in Airway Epithelial Cells Exposed to Type 2 Cytokines and Rhinovirus. J Innate Immun 2020;12:103-15. https://doi.org/10.1159/000497072.

[78] Ganesan S, Pham D, Jing Y, Farazuddin M, Hudy MH, Unger B, et al. TLR2 Activation Limits Rhinovirus-Stimulated CXCL-10 by Attenuating IRAK-1-Dependent IL-33 Receptor Signaling in Human Bronchial Epithelial Cells. J Immunol 2016;197:2409-20. https://doi.org/10.4049/jimmunol.1502702.

[79] Bluhmki T, Traub S, Müller A-K, Bitzer S, Schruf E, Bammert M-T, et al. Functional human iPSC-derived alveolar-like cells cultured in a miniaturized 96-Transwell air-liquid interface model. Sci Rep 2021;11:17028. https://doi.org/10.1038/s41598-021-96565-4.

[80] Bustamante J, Boisson-Dupuis S, Abel L, Casanova J-L. Mendelian susceptibility to mycobacterial disease: genetic, immunological, and clinical features of inborn errors of IFN- $\gamma$ immunity. Semin Immunol 2014;26:454-70. https://doi.org/10.1016/j.smim.2014.09.008.

[81] Rosain J, Kong X-F, Martinez-Barricarte R, Oleaga-Quintas C, Ramirez-Alejo N, Markle J, et al. Mendelian susceptibility to mycobacterial disease: 2014-2018 update. Immunol Cell Biol 2019;97:360-7. https://doi.org/10.1111/imcb.12210.

[82] Ciancanelli MJ, Huang SXL, Luthra P, Garner H, Itan Y, Volpi S, et al. Infectious disease. Life-threatening influenza and impaired interferon amplification in human IRF7 deficiency. Science 2015;348:448-53. https://doi.org/10.1126/science.aaa1578.

[83] York MR, Nagai T, Mangini AJ, Lemaire R, van Seventer JM, Lafyatis R. A macrophage marker, siglec-1, is increased on circulating monocytes in patients with systemic sclerosis and induced by type i interferons and toll-like receptor agonists. Arthritis Rheum 2007;56:1010-20. https://doi.org/10.1002/art.22382.

[84] Biesen R, Demir C, Barkhudarova F, Grün JR, Steinbrich-Zöllner M, Backhaus M, et al. Sialic acid-binding Ig-like lectin 1 expression in inflammatory and resident monocytes is a potential biomarker for monitoring disease activity and success of therapy in systemic lupus erythematosus. Arthritis Rheum 2008;58:1136-45. https://doi.org/10.1002/art.23404.

[85] Shao Y, Sztainberg Y, Wang Q, Bajikar SS, Trostle AJ, Wan Y-W, et al. Antisense oligonucleotide therapy in a humanized mouse model of MECP2 duplication syndrome. Sci Transl Med 2021;13:eaaz7785. https://doi.org/10.1126/scitranslmed.aaz7785. 
[86] Mohandas T, Geller RL, Yen PH, Rosendorff J, Bernstein R, Yoshida A, et al. Cytogenetic and molecular studies on a recombinant human $X$ chromosome: implications for the spreading of $X$ chromosome inactivation. Proc Natl Acad Sci U S A 1987;84:4954-8.

[87] Lammer EJ, Punglia DR, Fuchs AE, Rowe AG, Cotter PD. Inherited duplication of Xq27.2 $\leftarrow$ qter: phenocopy of infantile Prader-Willi syndrome. Clin Dysmorphol 2001;10:141-4.

[88] Akiyama M, Kawame H, Ohashi H, Tohma T, Ohta H, Shishikura A, et al. Functional disomy for Xq26.3-qter in a boy with an unbalanced $t(X ; 21)(q 26.3 ; p 11.2)$ translocation. Am J Med Genet 2001;99:111-4.

https://doi.org/10.1002/1096-8628(2001)9999:9999<::aid-ajmg1150>3.0.co;2-c.

[89] Rosenberg C, Knijnenburg J, Bakker E, Vianna-Morgante AM, Sloos W, Otto PA, et al. Array-CGH detection of micro rearrangements in mentally retarded individuals: clinical significance of imbalances present both in affected children and normal parents. J Med Genet 2006;43:180-6. https://doi.org/10.1136/jmg.2005.032268.

[90] Froyen G, Van Esch H, Bauters M, Hollanders K, Frints SGM, Vermeesch JR, et al. Detection of genomic copy number changes in patients with idiopathic mental retardation by high-resolution X-array-CGH: important role for increased gene dosage of XLMR genes. Hum Mutat 2007;28:1034-42. https://doi.org/10.1002/humu.20564.

[91] Madrigal I, Rodríguez-Revenga L, Armengol L, González E, Rodriguez B, Badenas C, et al. X-chromosome tiling path array detection of copy number variants in patients with chromosome X-linked mental retardation. BMC Genomics 2007;8:443. https://doi.org/10.1186/1471-2164-8-443.

[92] Bauters M, Van Esch H, Friez MJ, Boespflug-Tanguy O, Zenker M, Vianna-Morgante AM, et al. Nonrecurrent MECP2 duplications mediated by genomic architecture-driven DNA breaks and break-induced replication repair. Genome Res 2008;18:847-58. https://doi.org/10.1101/gr.075903.107.

[93] Ramocki MB, Peters SU, Tavyev YJ, Zhang F, Carvalho CMB, Schaaf CP, et al. Autism and other neuropsychiatric symptoms are prevalent in individuals with MeCP2 duplication syndrome. Ann Neurol 2009;66:771-82. https://doi.org/10.1002/ana.21715.

[94] Velinov M, Novelli A, Gu H, Fenko M, Dolzhanskaya N, Bernardini L, et al. De-novo 2.15 Mb terminal Xq duplication involving MECP2 but not L1CAM gene in a male patient with mental retardation. Clin Dysmorphol 2009;18:9-12. https://doi.org/10.1097/mcd.0b013e3283157cad.

[95] Echenne B, Roubertie A, Lugtenberg D, Kleefstra T, Hamel BCJ, Van Bokhoven H, et al. Neurologic aspects of MECP2 gene duplication in male patients. Pediatr Neurol 2009;41:187-91.

https://doi.org/10.1016/j.pediatrneurol.2009.03.012.

[96] Bartsch O, Gebauer K, Lechno S, Esch H van, Froyen G, Bonin M, et al. Four unrelated patients with lubs X-linked mental retardation syndrome and different Xq28 duplications. Am J Med Genet A 2010;152A:305-12. https://doi.org/10.1002/ajmg.a.33198.

[97] Honda S, Hayashi S, Imoto I, Toyama J, Okazawa H, Nakagawa E, et al. Copy-number variations on the X chromosome in Japanese patients with mental retardation detected by array-based comparative genomic hybridization analysis. J Hum Genet 2010;55:590-9. https://doi.org/10.1038/jhg.2010.74.

[98] Campos M, Churchman SM, Santos-Rebouças CB, Ponchel F, Pimentel MMG. High frequency of nonrecurrent MECP2 duplications among Brazilian males with mental retardation. J Mol Neurosci MN 2010;41:105-9. https://doi.org/10.1007/s12031-009-9296-2.

[99] Fernández RM, Núñez-Torres R, González-Meneses A, Antiñolo G, Borrego S. Novel association of severe neonatal encephalopathy and Hirschsprung disease in a male with a duplication at the Xq28 region. BMC Med Genet 2010;11:137. https://doi.org/10.1186/1471-2350-11-137.

[100] Kroes HY. Chromosomal abnormalities resembling Joubert syndrome: two cases illustrating the diagnostic pitfalls 2011.

[101] Neill NJ, Ballif BC, Lamb AN, Parikh S, Ravnan JB, Schultz RA, et al. Recurrence, submicroscopic complexity, and potential clinical relevance of copy gains detected by array CGH that are shown to be unbalanced insertions by FISH. Genome Res 2011;21:535-44. https://doi.org/10.1101/gr.114579.110.

[102] Budisteanu M, Papuc SM, Tutulan-Cunita A, Budisteanu B, Arghir A. Novel clinical finding in MECP2 duplication syndrome. Eur Child Adolesc Psychiatry 2011;20:373-5. https://doi.org/10.1007/s00787-011-0184-2.

[103] Jezela-Stanek A, Ciara E, Juszczak M, Pelc M, Materna-Kiryluk A, Krajewska-Walasek M. Cryptic x; autosome translocation in a boy--delineation of the phenotype. Pediatr Neurol 2011;44:221-4. https://doi.org/10.1016/j.pediatrneurol.2010.10.007.

[104] de Palma L, Boniver C, Cassina M, Toldo I, Nosadini M, Clementi M, et al. Eating-induced epileptic spasms in a boy with MECP2 duplication syndrome: insights into pathogenesis of genetic epilepsies. Epileptic Disord 2012;14:4147. https://doi.org/10.1684/epd.2012.0546.

[105] Vignoli A, Borgatti R, Peron A, Zucca C, Ballarati L, Bonaglia C, et al. Electroclinical pattern in MECP2 duplication syndrome: Eight new reported cases and review of literature. Epilepsia 2012;53:1146-55. https://doi.org/10.1111/j.1528-1167.2012.03501.x. 
[106] Xu X, Xu Q, Zhang Y, Zhang X, Cheng T, Wu B, et al. A case report of Chinese brothers with inherited MECP2containing duplication: autism and intellectual disability, but not seizures or respiratory infections. BMC Med Genet 2012;13:75. https://doi.org/10.1186/1471-2350-13-75.

[107] Utine GE, Kiper PÖ, Alanay Y, Haliloğlu G, Aktaş D, Boduroğlu K, et al. Searching for Copy Number Changes in Nonsyndromic X-Linked Intellectual Disability. Mol Syndromol 2012;2:64-71. https://doi.org/10.1159/000334289.

[108] Lund C, Brodtkorb E, Røsby O, Rødningen OK, Selmer KK. Copy number variants in adult patients with LennoxGastaut syndrome features. Epilepsy Res 2013;105:110-7. https://doi.org/10.1016/j.eplepsyres.2013.01.009.

[109] Peters SU, Hundley RJ, Wilson AK, Warren Z, Vehorn A, Carvalho C, et al. The behavioral phenotype in MECP2 duplication syndrome: A comparison to idiopathic autism. Autism Res Off J Int Soc Autism Res 2013;6:42-50. https://doi.org/10.1002/aur.1262.

[110] Peters SU, Hundley RJ, Wilson AK, Carvalho CMB, Lupski JR, Ramocki MB. Brief Report: Regression Timing and Associated Features in MECP2 Duplication Syndrome. J Autism Dev Disord 2013;43:2484-90. https://doi.org/10.1007/s10803-013-1796-9.

[111] Yamamoto T, Shimojima K, Shimada S, Yokochi K, Yoshitomi S, Yanagihara K, et al. Clinical impacts of genomic copy number gains at Xq28. Hum Genome Var 2014;1:14001. https://doi.org/10.1038/hgv.2014.1.

[112] Caumes R, Boespflug-Tanguy O, Villeneuve N, Lambert L, Delanoe C, Leheup B, et al. Late onset epileptic spasms is frequent in MECP2 gene duplication: Electroclinical features and long-term follow-up of 8 epilepsy patients. Eur $J$ Paediatr Neurol 2014;18:475-81. https://doi.org/10.1016/j.ejpn.2014.03.005.

[113] Nascimento FA, Faghfoury H, Krings T, Ali A, Fridhandler JD, Lozano A, et al. Deep brain stimulation for the management of seizures in MECP2 duplication syndrome. Seizure 2014;23:405-7. https://doi.org/10.1016/j.seizure.2014.01.021.

[114] Yi Z, Wang S, Li L, Wu H, Ma Y, Qi Y, et al. [Diagnosis of MECP2 duplication syndrome with molecular genetic techniques]. Zhonghua Er Ke Za Zhi Chin J Pediatr 2014;52:937-41.

[115] Wang Y, Zhang J, Qin L, Meng L, Jiang T, Ma D, et al. [Single nueleotide polymorphism array detection of Xq28 duplication in a child with mental retardation]. Zhonghua Er Ke Za Zhi Chin J Pediatr 2014;52:227-8.

[116] Lin D-S, Chuang T-P, Chiang M-F, Ho C-S, Hsiao C-D, Huang Y-W, et al. De novo MECP2 duplication derived from paternal germ line result in dysmorphism and developmental delay. Gene 2014;533:78-85. https://doi.org/10.1016/j.gene.2013.10.001.

[117] Zhang Q, Zhao Y, Yang Y, Bao X. MECP2 duplication syndrome in a Chinese family. BMC Med Genet 2015;16:112. https://doi.org/10.1186/s12881-015-0264-0.

[118] Voinova VY, Vorsanova SG, Yurov YB, Kolotiy AD, Davidova YI, Demidova IA, et al. [Clinical and genetic characteristics of the $X$ chromosome distal long arm microduplications encompassing the MECP2 gene]. Zh Nevrol Psikhiatr Im S S Korsakova 2015;115:10-6. https://doi.org/10.17116/jnevro201511510110-16.

[119] Magini P, Poscente M, Ferrari S, Vargiolu M, Bacchelli E, Graziano C, et al. Cytogenetic and molecular characterization of a recombinant $\mathrm{X}$ chromosome in a family with a severe neurologic phenotype and macular degeneration. Mol Cytogenet 2015;8:58. https://doi.org/10.1186/s13039-015-0164-1.

[120] El Chehadeh S, Faivre L, Mosca-Boidron A-L, Malan V, Amiel J, Nizon M, et al. Large national series of patients with Xq28 duplication involving MECP2: Delineation of brain MRI abnormalities in 30 affected patients. Am J Med Genet A 2016;170A:116-29. https://doi.org/10.1002/ajmg.a.37384.

[121] Ha K, Shen Y, Graves T, Kim C-H, Kim H-G. The presence of two rare genomic syndromes, 1q21 deletion and Xq28 duplication, segregating independently in a family with intellectual disability. Mol Cytogenet 2016;9:74. https://doi.org/10.1186/s13039-016-0286-0.

[122] Tug E, Ergun MA, Percin EF. MECP2 DUPLICATION SYNDROME WITH ADDITIONAL FINDINGS. Genet Couns Geneva Switz 2016;27:471-8.

[123] Tang D-X, Li D-F, Wu R-H, Zhang L-N, Luo X-Y. [MECP2 duplication syndrome: a clinical analysis of three cases and literature review]. Zhongguo Dang Dai Er Ke Za Zhi Chin J Contemp Pediatr 2017;19:489-93.

[124] Deshwar AR, Dupuis L, Bergmann C, Stavropoulos J, Mendoza-Londono R. Severe rhizomelic shortening in a child with a complex duplication/deletion rearrangement of chromosome X. Am J Med Genet A 2018;176:450-4. https://doi.org/10.1002/ajmg.a.38570.

[125] Jiang C, Pan N, Lyu W, Peng Y, Liu J, Guo R, et al. [Molecular diagnosis and functional study of a pedigree affected with Lubs X-linked mental retardation syndrome]. Zhonghua Yi Xue Yi Chuan Xue Za Zhi Zhonghua Yixue Yichuanxue Zazhi Chin J Med Genet 2019;36:340-3. https://doi.org/10.3760/cma.j.issn.1003-9406.2019.04.012.

[126] Hirabayashi K, Uehara DT, Abe H, Ishii A, Moriyama K, Hirose S, et al. Copy number variation analysis in 83 children with early-onset developmental and epileptic encephalopathy after targeted resequencing of a 109-epilepsy gene panel. J Hum Genet 2019;64:1097-106. https://doi.org/10.1038/s10038-019-0661-x.

[127] Liu J, Xi H, Peng Y, Pang J, Hu J, Ma N, et al. [Genetic analysis of a pedigree with MECP duplication syndrome]. Zhonghua Yi Xue Yi Chuan Xue Za Zhi Zhonghua Yixue Yichuanxue Zazhi Chin J Med Genet 2020;37:1146-9. https://doi.org/10.3760/cma.j.cn511374-20191014-00525. 
[128] Gutiérrez-Sánchez AM, Marín-Andrés M, López-Lafuente A, Monge-Galindo L, López-Pisón J, Peña-Segura JL. [Familial MECP2 duplication syndrome]. Rev Neurol 2020;70:309-10. https://doi.org/10.33588/rn.7008.2019457. 
Table 1 Overview of published patients suffering from $M E C P 2$ duplication syndrome. We included all publications describing patients with duplication or triplication of at least MECP2 and IRAK1. Also, we included publications describing patients with duplications in the region which included IRAKI although this gene was not described by then. Republished cases were only counted once as far as traceable. Note: Throughout the publications, the criteria for intellectual disability and developmental delay differ a lot. ND, not determined

\begin{tabular}{|c|c|c|c|c|c|c|c|c|c|c|}
\hline Reference & Country & \begin{tabular}{|l} 
Published \\
Patients
\end{tabular} & $\begin{array}{l}\text { There- } \\
\text { of } \\
\text { Male }\end{array}$ & $\begin{array}{l}\text { There- } \\
\text { of } \\
\text { Female }\end{array}$ & $\begin{array}{l}\text { Relatives } \\
\text { with } \\
\text { suspected } \\
\text { disease }\end{array}$ & $\begin{array}{l}\text { Intellectual } \\
\text { Disability or } \\
\text { Develop- } \\
\text { mental Delay }\end{array}$ & $\begin{array}{l}\text { Infantile } \\
\text { Hypotonia }\end{array}$ & $\begin{array}{l}\text { Epileptic } \\
\text { Seizures }\end{array}$ & $\begin{array}{l}\text { Recurrent } \\
\text { or Severe } \\
\text { Infections }\end{array}$ & $\begin{array}{l}\text { Thereof } \\
\text { Respiratory } \\
\text { Infections }\end{array}$ \\
\hline Mohandas 1987 [86] & USA & 1 & 1 & & & $1 / 1$ & ND & ND & ND & ND \\
\hline Bertini 1992 [54] & Italy & 2 & 2 & & 5 & $2 / 2$ & $2 / 2$ & $2 / 2$ & $2 / 2$ & $2 / 2$ \\
\hline Lahn 1994 [55] & USA & 3 & 3 & & & $3 / 3$ & $3 / 3$ & $3 / 3$ & ND & ND \\
\hline Vasquez 1995 [25] & Mexico & 2 & 2 & & 1 & $2 / 2$ & $2 / 2$ & ND & $2 / 2$ & $2 / 2$ \\
\hline Pai 1997 [26] & USA & 5 & 5 & & 1 & $5 / 5$ & ND & $4 / 5$ & $4 / 4$ & $4 / 4$ \\
\hline Goodman 1998 [71] & USA & 4 & 4 & & 1 & $4 / 4$ & $4 / 4$ & $1 / 4$ & $2 / 4$ & $2 / 2$ \\
\hline Lubs 1999 [7] & USA & 5 & 5 & & & $5 / 5$ & $5 / 5$ & $2 / 5$ & $5 / 5$ & $5 / 5$ \\
\hline Lammer 2001 [87] & USA & 1 & 1 & & 3 & $1 / 1$ & $1 / 1$ & ND & $1 / 1$ & $1 / 1$ \\
\hline Akiyama 2001 [88] & Japan & 1 & 1 & & & $1 / 1$ & $1 / 1$ & $1 / 1$ & $1 / 1$ & $1 / 1$ \\
\hline Bialer 2003 [7] & USA & 1 & & 1 & & $1 / 1$ & $1 / 1$ & ND & $1 / 1$ & $1 / 1$ \\
\hline Novelli 2004 [52] & Italy & 1 & 1 & & & $1 / 1$ & $1 / 1$ & ND & $1 / 1$ & $1 / 1$ \\
\hline $\begin{array}{l}\text { Kokalj-Vokac } 2004 \\
{[58]}\end{array}$ & Slovenia & 1 & 1 & & & $1 / 1$ & $1 / 1$ & $0 / 1$ & $1 / 1$ & $1 / 1$ \\
\hline Lachlan 2004 [8] & UK & 2 & 1 & 1 & & $2 / 2$ & $2 / 2$ & $0 / 2$ & $2 / 2$ & $1 / 1$ \\
\hline Teek 2004 [28] & Estonia & 1 & 1 & & & $1 / 1$ & ND & ND & $1 / 1$ & $1 / 1$ \\
\hline Meins 2005 [2] & Germany & 1 & 1 & & & $1 / 1$ & $1 / 1$ & $1 / 1$ & $1 / 1$ & $1 / 1$ \\
\hline Sanlaville $2005^{\text {a }}$ [9] & France & 2 & 1 & 1 & & $2 / 2$ & $2 / 2$ & $0 / 2$ & $2 / 2$ & $2 / 2$ \\
\hline Van Esch 2005 [1] & Belgium & 13 & 13 & & & $12 / 12$ & $11 / 11$ & $4 / 9$ & $5 / 9$ & $5 / 5$ \\
\hline Friez $2006^{\text {a }}$ [29] & USA & 13 & 13 & & & $13 / 13$ & $12 / 13$ & $9 / 13$ & $13 / 13$ & $12 / 12$ \\
\hline Rosenberg 2006 [89] & Brazil & 1 & 1 & & 2 & $1 / 1$ & ND & ND & ND & ND \\
\hline del Gaudio 2006 [4] & USA & 7 & 7 & & & $7 / 7$ & $7 / 7$ & $1 / 7$ & $4 / 7$ & $4 / 4$ \\
\hline Froyen $2007^{\text {b }}$ [90] & Belgium & & & & & & & & & \\
\hline Madrigal 2007 [91] & Spain & 1 & 1 & & 2 & $1 / 1$ & $1 / 1$ & ND & $1 / 1$ & $1 / 1$ \\
\hline Bauters $2008^{\text {a }}$ [92] & France & 4 & 4 & & & ND & ND & ND & $1 / 1$ & $1 / 1$ \\
\hline Smyk 2008 [30] & Poland & 3 & 3 & & 2 & $3 / 3$ & $3 / 3$ & $1 / 3$ & $3 / 3$ & $2 / 2$ \\
\hline Lugtenberg 2009 [6] & Netherlands & 13 & 13 & & 1 & $13 / 13$ & $13 / 13$ & $7 / 13$ & $3 / 13$ & $3 / 3$ \\
\hline $\begin{array}{l}\text { Clayton-Smith } 2009 \\
\text { [5] }\end{array}$ & UK & 15 & 15 & & & $14 / 15$ & $12 / 15$ & $8 / 15$ & $14 / 15$ & $14 / 14$ \\
\hline Prescott 2009 [31] & Norway & 2 & 2 & & & $2 / 2$ & ND & $1 / 2$ & $2 / 2$ & $2 / 2$ \\
\hline Ramocki $2009^{\text {a }}$ [93] & USA & 8 & 8 & & 5 & $8 / 8$ & $8 / 8$ & $4 / 8$ & $6 / 8$ & $6 / 6$ \\
\hline Velinov 2009 [94] & USA & 1 & 1 & & & $1 / 1$ & $1 / 1$ & $0 / 1$ & $0 / 1$ & ND \\
\hline Echenne 2009 [95] & France & 5 & 5 & & & $5 / 5$ & $5 / 5$ & $4 / 5$ & $0 / 5$ & ND \\
\hline Kirk 2009 [32] & Australia & 3 & 3 & & & $3 / 3$ & $1 / 1$ & $2 / 2$ & $2 / 2$ & $2 / 2$ \\
\hline Bartsch 2010 [96] & Germany & 4 & 4 & & & $4 / 4$ & $4 / 4$ & $2 / 4$ & $4 / 4$ & $2 / 2$ \\
\hline Honda $2010^{\mathrm{c}}$ [97] & Japan & & & & & & & & & \\
\hline Belligni 2010 [53] & Italy & 1 & 1 & & & $1 / 1$ & $1 / 1$ & ND & $1 / 1$ & $1 / 1$ \\
\hline Reardon 2010 [12] & Ireland & 8 & 7 & 1 & & $8 / 8$ & $2 / 2$ & $4 / 8$ & $7 / 8$ & $7 / 7$ \\
\hline Auber 2010 [10] & Germany & 1 & & 1 & & $1 / 1$ & $1 / 1$ & $1 / 1$ & $1 / 1$ & $1 / 1$ \\
\hline
\end{tabular}




\begin{tabular}{|c|c|c|c|c|c|c|c|c|c|c|}
\hline Campos 2010 [98] & Brazil & 3 & 3 & & & $3 / 3$ & $1 / 1$ & $2 / 2$ & ND & ND \\
\hline Fernandez 2010 [99] & Spain & 1 & 1 & & 1 & $1 / 1$ & $1 / 1$ & $1 / 1$ & $1 / 1$ & $1 / 1$ \\
\hline Kroes 2011 [100] & Netherlands & 1 & 1 & & & $1 / 1$ & $1 / 1$ & ND & $1 / 1$ & $1 / 1$ \\
\hline Neill 2011 [101] & USA & 1 & 1 & & & $1 / 1$ & ND & ND & ND & ND \\
\hline Mayo 2011 [13] & Spain & 1 & & 1 & & $1 / 1$ & $0 / 1$ & $1 / 1$ & ND & ND \\
\hline Budisteanu 2011 [102] & Romania & 1 & 1 & & & $1 / 1$ & $1 / 1$ & $0 / 1$ & $1 / 1$ & $1 / 1$ \\
\hline Grasshoff 2011 [14] & Germany & 2 & & 2 & & $2 / 2$ & ND & $0 / 2$ & $1 / 2$ & $1 / 1$ \\
\hline Breman 2011 [72] & USA & 6 & 6 & & & $6 / 6$ & $6 / 6$ & $0 / 6$ & $5 / 6$ & ND \\
\hline $\begin{array}{l}\text { Jezela-Stanek } 2011 \\
\text { [103] }\end{array}$ & Poland & 1 & 1 & & & $1 / 1$ & $1 / 1$ & $1 / 1$ & $1 / 1$ & $1 / 1$ \\
\hline Carvalho $2011^{\text {a }}$ [33] & USA & 7 & 7 & & & $7 / 7$ & $7 / 7$ & $2 / 7$ & $6 / 6$ & $6 / 6$ \\
\hline Honda 2012 [34] & Japan & 12 & 12 & & & $12 / 12$ & $10 / 12$ & $9 / 12$ & $10 / 12$ & $10 / 10$ \\
\hline Honda 2012 [35] & Japan & 2 & 2 & & 1 & $2 / 2$ & $2 / 2$ & $2 / 2$ & $2 / 2$ & $1 / 1$ \\
\hline Van Esch 2012 [22] & Belgium & 15 & 15 & & & $13 / 13$ & $14 / 14$ & $8 / 14$ & $9 / 13$ & ND \\
\hline Bijlsma $2012^{a}$ [15] & USA & 4 & & 4 & & $3 / 4$ & $2 / 4$ & $0 / 4$ & $3 / 4$ & $2 / 3$ \\
\hline De Palma 2012 [104] & Italy & 1 & 1 & & & $1 / 1$ & ND & $1 / 1$ & $1 / 1$ & $1 / 1$ \\
\hline Vignoli 2012 [105] & Italy & 8 & 8 & & & $8 / 8$ & $5 / 5$ & $6 / 8$ & $6 / 6$ & $6 / 6$ \\
\hline Sanmann 2012 [73] & USA & 6 & 6 & & 4 & $6 / 6$ & $3 / 3$ & $2 / 2$ & $5 / 5$ & $5 / 5$ \\
\hline Xu 2012 [106] & China & 2 & 2 & & & $2 / 2$ & $2 / 2$ & $0 / 2$ & $0 / 2$ & ND \\
\hline Utine 2012 [107] & Turkey & 1 & 1 & & & $1 / 1$ & $1 / 1$ & $0 / 1$ & $1 / 1$ & $1 / 1$ \\
\hline Tang 2012 [36] & UK & 2 & 2 & & & $3 / 3$ & $3 / 3$ & $2 / 2$ & $3 / 3$ & $3 / 3$ \\
\hline Lund 2013 [108] & Norway & 1 & 1 & & & $1 / 1$ & $1 / 1$ & $1 / 1$ & $1 / 1$ & $1 / 1$ \\
\hline Peters $2013^{c}[109]$ & USA & 10 & 10 & & & ND & $9 / 10$ & ND & $10 / 10$ & ND \\
\hline Peters $2013^{c}[110]$ & USA & 6 & 6 & & & ND & ND & ND & ND & ND \\
\hline Shimada 2013 [37] & Japan & 4 & 3 & 1 & & $4 / 4$ & $3 / 3$ & $3 / 4$ & $4 / 4$ & $3 / 3$ \\
\hline Shimada 2013 [16] & Japan & 3 & 2 & 1 & & $3 / 3$ & $3 / 3$ & $3 / 3$ & $3 / 3$ & $3 / 3$ \\
\hline $\begin{array}{l}\text { Yamamoto } 2014^{\text {a }} \\
\text { [111] }\end{array}$ & Japan & 4 & 4 & & & $4 / 4$ & $2 / 2$ & $3 / 4$ & $1 / 1$ & ND \\
\hline Caumes 2014 [112] & France & 8 & 8 & & & $8 / 8$ & $8 / 8$ & $8 / 8$ & $3 / 8$ & ND \\
\hline $\begin{array}{l}\text { Scott Schwoerer } 2014 \\
{[17]}\end{array}$ & USA & 2 & & 2 & & $2 / 2$ & $2 / 2$ & $2 / 2$ & $1 / 2$ & $1 / 1$ \\
\hline Fukushi 2014 [38] & Japan & 5 & 5 & & & $5 / 5$ & $4 / 4$ & $5 / 5$ & $5 / 5$ & $4 / 4$ \\
\hline Fieremans 2014 [18] & Belgium & 2 & & 2 & & $2 / 2$ & ND & $0 / 1$ & ND & ND \\
\hline Nascimento 2014 [113] & Canada & 1 & 1 & & & $1 / 1$ & ND & $1 / 1$ & ND & ND \\
\hline Yi $2014^{\text {d }}$ [114] & China & & & & & & & & & \\
\hline Wang $2014^{\mathrm{d}}$ [115] & China & & & & & & & & & \\
\hline Novara 2014 [19] & Italy & 3 & & 3 & 2 & $3 / 3$ & $3 / 3$ & ND & $0 / 3$ & ND \\
\hline Lin 2014 [116] & Taiwan & 1 & 1 & & & $1 / 1$ & $1 / 1$ & $1 / 1$ & $1 / 1$ & $1 / 1$ \\
\hline Chow 2015 [39] & Singapore & 3 & 3 & & & $3 / 3$ & $3 / 3$ & $3 / 3$ & $3 / 3$ & $3 / 3$ \\
\hline Bauer 2015 [40] & Germany & 12 & 12 & & & ND & ND & ND & $10 / 10$ & $9 / 10$ \\
\hline Zhang 2015 [117] & China & 1 & 1 & & 2 & $1 / 1$ & $1 / 1$ & $0 / 1$ & $1 / 1$ & $1 / 1$ \\
\hline Voinova 2015 [118] & Russia & 4 & 4 & & & $4 / 4$ & $4 / 4$ & $2 / 4$ & $4 / 4$ & ND \\
\hline Magini $2015^{\text {b }}$ [119] & Italy & & & & & & & & & \\
\hline Yi 2016 [41] & China & 16 & 15 & 1 & & $16 / 16$ & $16 / 16$ & $6 / 16$ & $16 / 16$ & ND \\
\hline $\begin{array}{l}\text { El Chehadeh } 2016^{\mathrm{c}} \\
\text { [120] }\end{array}$ & France & & & & & ND & ND & $15 / 30$ & ND & ND \\
\hline
\end{tabular}




\begin{tabular}{|c|c|c|c|c|c|c|c|c|c|c|}
\hline На 2016 [121] & USA & 1 & 1 & & 1 & $1 / 1$ & $1 / 1$ & $0 / 1$ & ND & ND \\
\hline Tug 2016 [122] & Turkey & 1 & 1 & & & $1 / 1$ & $1 / 1$ & $0 / 1$ & $1 / 1$ & $\mathrm{ND}$ \\
\hline $\begin{array}{l}\text { Trobaugh-Lotrario } \\
2016 \text { [42] }\end{array}$ & USA & 1 & 1 & & & $1 / 1$ & $\mathrm{ND}$ & $1 / 1$ & $1 / 1$ & $1 / 1$ \\
\hline $\begin{array}{l}\text { San Antonio-Arce } \\
2016[20]\end{array}$ & Spain & 2 & & 2 & & $2 / 2$ & $1 / 2$ & $1 / 2$ & $2 / 2$ & $2 / 2$ \\
\hline Lim 2017 [75] & Australia & 56 & 49 & 7 & & $45 / 55$ & $35 / 55$ & $24 / 45$ & $41 / 56$ & $41 / 41$ \\
\hline El Chehadeh 2017 [21] & France & 4 & & 4 & & $4 / 4$ & $3 / 4$ & $2 / 4$ & $3 / 4$ & $0 / 2$ \\
\hline $\begin{array}{l}\text { Moirangthem } 2017 \\
\text { [43] }\end{array}$ & India & 2 & 2 & & 3 & $2 / 2$ & $1 / 1$ & $0 / 2$ & $1 / 2$ & $1 / 1$ \\
\hline $\begin{array}{l}\text { Tsuji-Hosokawa } 2017 \\
\text { [44] }\end{array}$ & Japan & 1 & 1 & & & $1 / 1$ & ND & $0 / 1$ & $1 / 1$ & $1 / 1$ \\
\hline Yon 2017 [51] & Korea & 2 & 2 & & & $2 / 2$ & $2 / 2$ & $2 / 2$ & $2 / 2$ & $2 / 2$ \\
\hline Tang $2017^{\mathrm{d}}[123]$ & China & 3 & 3 & & & $2 / 2$ & $3 / 3$ & $2 / 2$ & $3 / 3$ & ND \\
\hline Li 2017 [45] & China & 5 & 5 & & 1 & $5 / 5$ & $5 / 5$ & $4 / 5$ & $4 / 5$ & $4 / 4$ \\
\hline Deshwar 2018 [124] & Canada & 1 & 1 & & & $1 / 1$ & $1 / 1$ & ND & $1 / 1$ & $1 / 1$ \\
\hline Miguet 2018 [23] & France & 86 & 86 & & & $59 / 59$ & $57 / 58$ & $35 / 59$ & $49 / 55$ & $49 / 49$ \\
\hline $\begin{array}{l}\text { Giudice-Nairn } 2019^{\mathrm{c}} \\
\text { [46] } \\
\text { Jiang } 2019^{\mathrm{d}}[125]\end{array}$ & $\begin{array}{l}\text { Australia } \\
\text { China }\end{array}$ & 20 & 16 & 4 & & $19 / 20$ & $15 / 20$ & $11 / 20$ & $18 / 20$ & $15 / 18$ \\
\hline Peters 2019 [24] & USA & 48 & 43 & 5 & & $31 / 48$ & $42 / 48$ & $21 / 48$ & $27 / 48$ & $27 / 27$ \\
\hline $\begin{array}{l}\text { Hirabayashi } 2019 \\
{[126]}\end{array}$ & Japan & 1 & 1 & & & $1 / 1$ & $1 / 1$ & $1 / 1$ & $1 / 1$ & ND \\
\hline $\begin{array}{l}\text { Pascual-Alonso } 2020^{\text {a }} \\
\text { [47] }\end{array}$ & Spain & 19 & 18 & 1 & & $19 / 19$ & $17 / 19$ & $19 / 19$ & $14 / 18$ & $14 / 14$ \\
\hline Choi 2020 [76] & Hong Kong & 1 & 1 & & & $1 / 1$ & $1 / 1$ & $0 / 1$ & $1 / 1$ & $1 / 1$ \\
\hline $\begin{array}{l}\text { Tekendo-Ngongang } \\
2020[48]\end{array}$ & Cameroon & 1 & 1 & & 1 & $1 / 1$ & $1 / 1$ & $1 / 1$ & $1 / 1$ & $1 / 1$ \\
\hline van Baelen 2020 [49] & Belgium & 3 & 3 & & & $2 / 2$ & $2 / 2$ & ND & $3 / 3$ & $3 / 3$ \\
\hline Liu $2020^{d}$ [127] & China & & & & & & & & & \\
\hline $\begin{array}{l}\text { Gutierrez-Sanchez } \\
2020^{\mathrm{c}}[128]\end{array}$ & Spain & 2 & 2 & & & $2 / 2$ & $1 / 1$ & ND & $2 / 2$ & $1 / 1$ \\
\hline \multirow[t]{4}{*}{ Takeguchi 2021 [56] } & Japan & 24 & 24 & & & $18 / 18$ & $18 / 21$ & $16 / 24$ & $18 / 23$ & $14 / 18$ \\
\hline & & $\begin{array}{l}\text { Published } \\
\text { Patients }\end{array}$ & $\begin{array}{l}\text { There- } \\
\text { of } \\
\text { Male }\end{array}$ & $\begin{array}{l}\text { There- } \\
\text { of } \\
\text { Female }\end{array}$ & $\begin{array}{l}\text { Relatives } \\
\text { with } \\
\text { suspected } \\
\text { disease } \\
\end{array}$ & $\begin{array}{l}\text { Intellectual } \\
\text { Disability or } \\
\text { Develop- } \\
\text { mental Delay }\end{array}$ & $\begin{array}{l}\text { Infantile } \\
\text { Hypotonia }\end{array}$ & $\begin{array}{l}\text { Epileptic } \\
\text { Seizures }\end{array}$ & $\begin{array}{l}\text { Recurrent } \\
\text { or Severe } \\
\text { Infections }\end{array}$ & $\begin{array}{l}\text { Thereof } \\
\text { Respiratory } \\
\text { Infections }\end{array}$ \\
\hline & & 545 & 504 & 41 & 39 & $462 / 491$ & $411 / 454$ & $257 / 459$ & $376 / 479$ & $316 / 324$ \\
\hline & & & $92 \%$ & $8 \%$ & & $94 \%$ & $91 \%$ & $56 \%$ & $78 \%$ & $98 \%$ \\
\hline
\end{tabular}


Table 2 Clinical baseline characteristics of the cohort. UTI, urinary tract infections; SV40, SV40 immortalized fibroblasts; PBMCs, peripheral blood mononuclear cells; ND, not determined

\begin{tabular}{|c|c|c|c|c|c|c|c|c|c|c|c|c|}
\hline \multirow[t]{2}{*}{ Patient } & \multirow[t]{2}{*}{ Sex } & \multirow{2}{*}{$\begin{array}{l}\text { Age at Last } \\
\text { Consultation }\end{array}$} & \multirow[t]{2}{*}{ Origin } & \multirow{2}{*}{\begin{tabular}{|l|} 
Intellectual \\
Disability or \\
Developmental \\
Delay \\
\end{tabular}} & \multirow{2}{*}{$\begin{array}{l}\text { Infantile } \\
\text { Hypotonia }\end{array}$} & \multirow{2}{*}{$\begin{array}{l}\text { Epileptic } \\
\text { Seizures }\end{array}$} & \multirow{2}{*}{$\begin{array}{l}\text { Recurrent } \\
\text { or Severe } \\
\text { Infections }\end{array}$} & \multicolumn{4}{|l|}{ Number of } & \multirow[t]{2}{*}{ Material } \\
\hline & & & & & & & & Pneumonia & Sepsis & UTI & $\begin{array}{l}\text { Purulent } \\
\text { Otitis }\end{array}$ & \\
\hline $1 \mathrm{a}$ & male & $15 \dagger$ & Germany & $x$ & $\mathrm{x}$ & $\mathrm{x}$ & $\mathrm{x}$ & 14 & 0 & 7 & 2 & SV40 \\
\hline $2^{a}$ & male & $15 \dagger$ & Belgium & $x$ & $\mathrm{x}$ & $\mathrm{x}$ & $\mathrm{x}$ & 50 & 1 & ND & 3 & SV40 \\
\hline $3^{a}$ & male & 25 & Germany & $\mathrm{x}$ & $\mathrm{x}$ & $\mathrm{x}$ & $\mathrm{x}$ & 58 & $>5$ & $>1$ & $>3$ & $\begin{array}{l}\text { SV40, } \\
\text { PBMCs, } \\
\text { whole blood }\end{array}$ \\
\hline $4^{\mathrm{a}}$ & male & 8 & France & $\mathrm{x}$ & $\mathrm{x}$ & ND & $\mathrm{x}$ & 2 & 0 & ND & $>4$ & SV40 \\
\hline 5 & male & 21 & Belgium & $\mathrm{x}$ & $\mathrm{x}$ & $\mathrm{x}$ & $\mathrm{x}$ & 32 & 1 & 1 & ND & $\begin{array}{l}\text { PBMCs, } \\
\text { whole blood }\end{array}$ \\
\hline 6 & male & 10 & Belgium & $x$ & $\mathrm{x}$ & $\mathrm{x}$ & $\mathrm{x}$ & 3 & 0 & 0 & ND & $\begin{array}{l}\text { PBMCs, } \\
\text { whole blood }\end{array}$ \\
\hline 7 & male & 5 & Poland & $x$ & $\mathrm{x}$ & I & $\mathrm{x}$ & 5 & 1 & 2 & ND & $\begin{array}{l}\text { PBMCs, } \\
\text { whole blood }\end{array}$ \\
\hline 8 & male & 10 & Germany & $x$ & $\mathrm{x}$ & I & $\mathrm{x}$ & $>1$ & 0 & ND & ND & $\begin{array}{l}\text { PBMCs, } \\
\text { whole blood }\end{array}$ \\
\hline \multirow[t]{2}{*}{$9^{a}$} & male & 10 & Germany & $x$ & $\mathrm{x}$ & ND & $\mathrm{x}$ & 7 & ND & 5 & 1 & $\begin{array}{l}\text { PBMCs, } \\
\text { whole blood }\end{array}$ \\
\hline & & & & $9 / 9$ & $9 / 9$ & $5 / 7$ & $9 / 9$ & & & & & \\
\hline
\end{tabular}

${ }^{a}$ published elsewhere, see Online Electronic Supplementary Material

$\dagger$ deceased 
Fig. 1 Canonical pathway of NF- $\kappa$ B signaling. Upon binding of ligands, such as IL-1 to the IL-1R, LPS to TLR4 or diacylated lipopeptides like PAM2CSK4 to TLR2/6, the inflammatory signaling is mediated via the myddosome complex which consists of MyD88 and IRAK family kinases. MyD88 associates with IRAK4 via a homophilic interaction between their death domains. IRAK4 induces the phosphorylation of IRAK1. The hyperphosphorylated IRAK1 then dissociates from the complex and associates with TRAF6 to activate TAK-1/TAB complex. The latter enhances the activity of the IKK complex

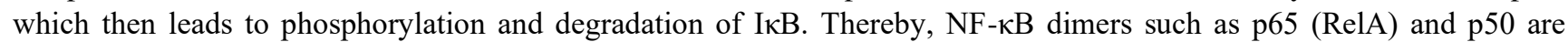
activated and migrate into the nucleus which results in gene transcription and the induction of inflammatory cytokines. Adapted from Heller S, Kölsch U, Magg T, et al. T Cell Impairment Is Predictive for a Severe Clinical Course in NEMO

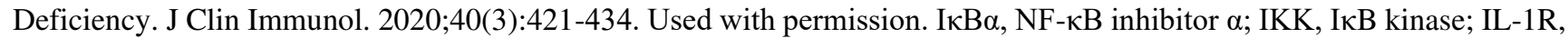
interleukin-1 receptor; IRAK, interleukin-1 receptor-associated kinase; LPS, lipopolysaccharide; MyD88, myeloid differentiation primary response 88; TAB, TAK1-binding proteins; TAK-1, TGF- $\beta$-activated kinase 1 ; TLR, toll-like receptor; TRAF, TNF receptor-associated factor. The canonical NF- $\kappa \mathrm{B}$ pathway can be disturbed through disease-causing mutations within multiple genes. Described correlations between phenotype and genotype are listed in the OMIM database (OMIM numbers: IאB $\alpha^{*} 164008$, IKK $\alpha * 600664$, IKK $\beta * 603258$, IKK $\gamma^{*} 300248$, IRAK1*300283, IRAK4*606883, MyD88*602170, p50*164011, p65*164014).

Fig. 2 Size of duplications on chromosome Xq28 based on human genome assembly GRCh37 (hg19) in mega base pairs $(\mathrm{Mb})$. Position of IRAKI is indicated in red and position of MECP2 is indicated in green. Vertical dotted lines show the minimal duplicated region including IRAKI and MECP2.* Black bars with a star indicate triplicated segments. This figure was created using Prism 9 (GraphPad).

Fig. 3 Characterization of SV40-immortalized fibroblasts. Western blot analysis of IRAK-1 and IRAK-4 protein levels in cell lysates from SV40-immortalized fibroblasts of healthy controls $(\mathrm{n}=4)$, patients $(\mathrm{n}=4)$, an IRAKI-deficient patient and an IRAK4-deficient patient. Pictures were cropped and adjusted. Quantitation is shown in Table S2.

Fig. 4 Cytokine production upon stimulation measured in cell culture supernatants. Bars indicate median values. a and $\mathbf{b}$ Cytokine production in patients' SV40-immortalized fibroblasts $(\mathrm{n}=4)$ upon stimulation with IL-1 $(0,1 \mathrm{ng} / \mathrm{ml})$, TLR-

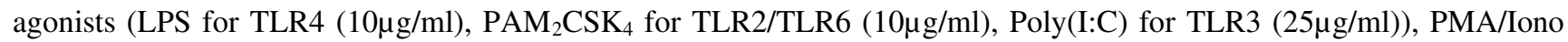
$\left(1 \times 10^{-7} \mathrm{M} / 1 \times 10^{-5} \mathrm{M}\right)$ and TNF- $\alpha(20 \mathrm{ng} / \mathrm{ml})$. SV40-immortalized fibroblasts of healthy controls (n=4), an IRAK1-null patient and an IRAK4-null patient were used as intra-assay controls. a IL-6 production. b IL-8 production. c and d Cytokine production in patients' PBMCs upon stimulation with IL-1 $\beta(1 \mathrm{ng} / \mathrm{ml})$, TLR-agonists (LPS for TLR4 (1ng/ml), PAM ${ }_{2}$ CSK 4 for TLR2/TLR6 $(1 \mu \mathrm{g} / \mathrm{ml}))$, PMA/Iono $\left(1 \times 10^{-7} \mathrm{M} / 1 \times 10^{-5} \mathrm{M}\right)$ and TNF- $\alpha(20 \mathrm{ng} / \mathrm{ml})$. SV40-immortalized fibroblasts of healthy controls $(n=4)$ were used as intra-assay controls. $\mathbf{c}$ IL-6 production $(n=8)$. d IL-8 production $(n=7)$. * zero values. e and $\mathbf{f}$ Cytokine production in patients' whole blood $(\mathrm{n}=6)$ upon stimulation with IL-1 $\beta(20 \mathrm{ng} / \mathrm{ml})$, TLR-agonists (LPS for TLR4 (1ng/ml), $\mathrm{PAM}_{2} \mathrm{CSK}_{4}$ for TLR2/TLR6 (100ng/ml)), PMA/Iono (1x10 $\left.0^{-7} \mathrm{M} / 1 \times 10^{-5} \mathrm{M}\right)$ and TNF- $\alpha$ (20ng/ml). The analyses were performed in comparison to a cohort of healthy controls assessed in our laboratory $(\mathrm{n}=179$, whiskers 5-95 percentile). e IL-6 production. f IL-10 production. This figure was created using Prism 9 (GraphPad). IRAK1, IL-1 receptor-associated kinase 1; IL-1 $\beta$, interleukin-1 $\beta$; LPS, lipopolysaccharide; $\mathrm{PAM}_{2}, \mathrm{PAM}_{2} \mathrm{CSK}_{4} ; \mathrm{PMA} / \mathrm{I}$, phorbol myristate acetate/ ionomycin; TLR, toll-like receptor; TNF- $\alpha$, tumor necrosis factor $\alpha$

Fig. 5 Immunological phenotype of SV40-immortalized fibroblasts. a IRAK1 phosphorylation upon stimulation with IL-1 $\beta$ (10 ng/ml), TLR4-agonist LPS $(10 \mu \mathrm{g} / \mathrm{ml})$ and TNF- $\alpha(20 \mathrm{ng} / \mathrm{ml})$. Cell lysates were analyzed by performing western blots specific to IRAK1, I $\kappa \mathrm{B} \alpha$ and GAPDH. Phosphorylated IRAK1 can be seen as smear above the band of the nonphosphorylated IRAK1. GAPDH was used as a loading control. b IкB $\alpha$-degradation upon stimulation with IL-1 $\beta$ (10 ng/ml). Cell lysates were analyzed by performing western blots specific to $\mathrm{I} \kappa \mathrm{B} \alpha$ and p38MAPK. P38MAPK was used as a loading

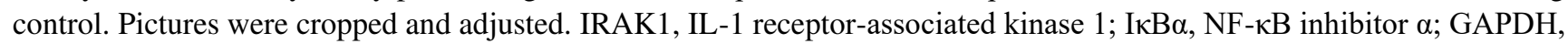
glyceraldehyde-3-phosphate-dehydrogenase; IL-1 $\beta$, interleukin-1 $\beta$; LPS, lipopolysaccharide; p38MAPK, p38-mitogen activated protein kinase; TNF- $\alpha$, tumor necrosis factor $\alpha$ 


\section{Figures}

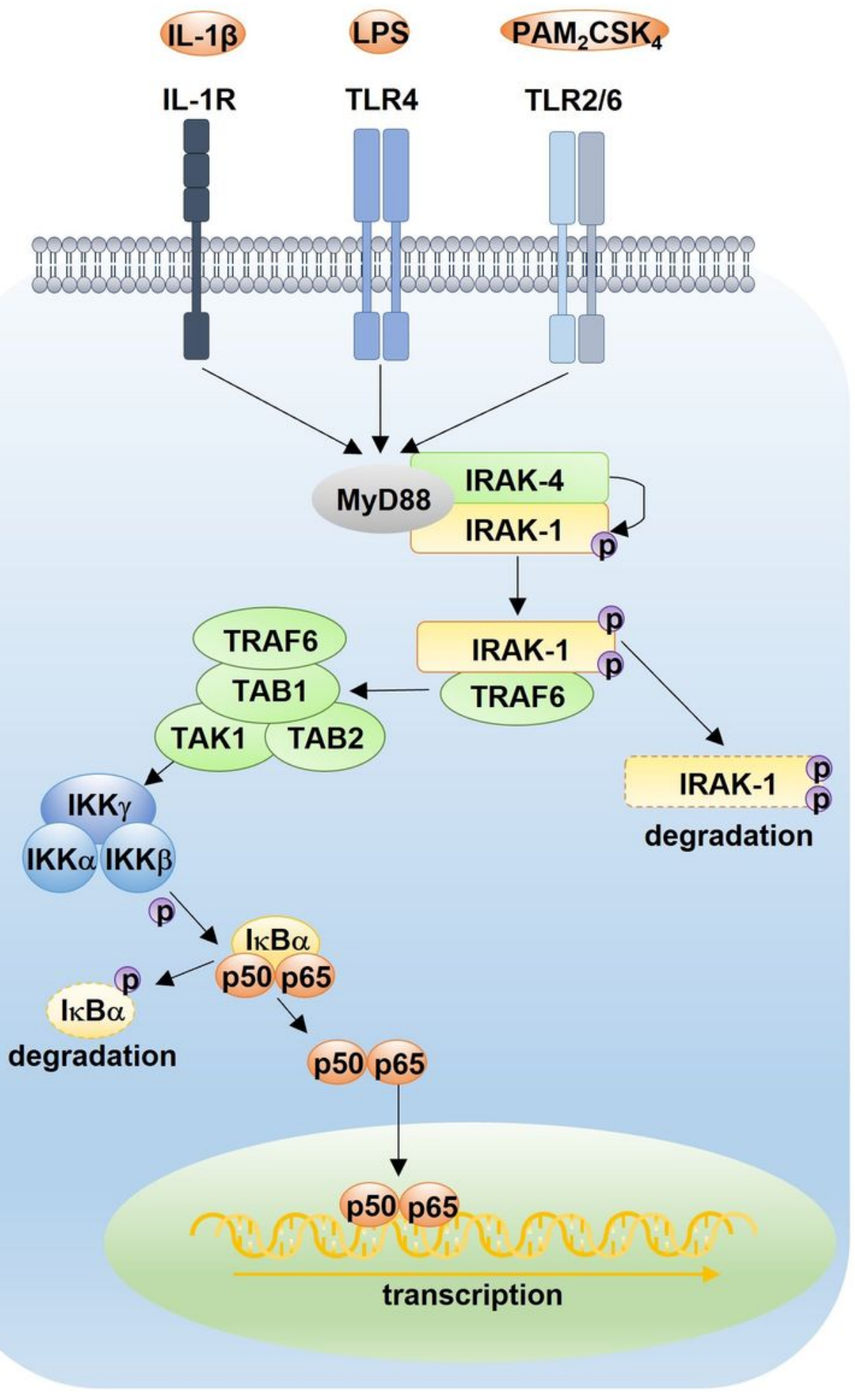

Figure 1

Canonical pathway of NF-KB signaling. Upon binding of ligands, such as IL-1 to the IL-1R, LPS to TLR4 or diacylated lipopeptides like PAM2CSK4 to TLR2/6, the inflammatory signaling is mediated via the myddosome complex which consists of MyD88 and IRAK family kinases. MyD88 associates with IRAK4 
via a homophilic interaction between their death domains. IRAK4 induces the phosphorylation of IRAK1. The hyperphosphorylated IRAK1 then dissociates from the complex and associates with TRAF6 to activate TAK-1/TAB complex. The latter enhances the activity of the IKK complex which then leads to phosphorylation and degradation of ІкB. Thereby, NF-KB dimers such as p65 (RelA) and p50 are activated and migrate into the nucleus which results in gene transcription and the induction of inflammatory cytokines. Adapted from Heller S, Kölsch U, Magg T, et al. T Cell Impairment Is Predictive for a Severe Clinical Course in NEMO Deficiency. J Clin Immunol. 2020;40(3):421-434. Used with permission. IKBa, NFKB inhibitor a; IKK, IKB kinase; IL-1R, interleukin-1 receptor; IRAK, interleukin-1 receptor-associated kinase; LPS, lipopolysaccharide; MyD88, myeloid differentiation primary response 88; TAB, TAK1-binding proteins; TAK-1, TGF- $\beta$-activated kinase 1; TLR, toll-like receptor; TRAF, TNF receptor-associated factor. The canonical NF-KB pathway can be disturbed through disease-causing mutations within multiple genes. Described correlations between phenotype and genotype are listed in the OMIM database (OMIM numbers: IKBa*164008, IKKa*600664, IKK ${ }^{\star} 603258$, IKKY*300248, IRAK1*300283, IRAK4*606883, MyD88*602170, p50*164011, p65*164014).

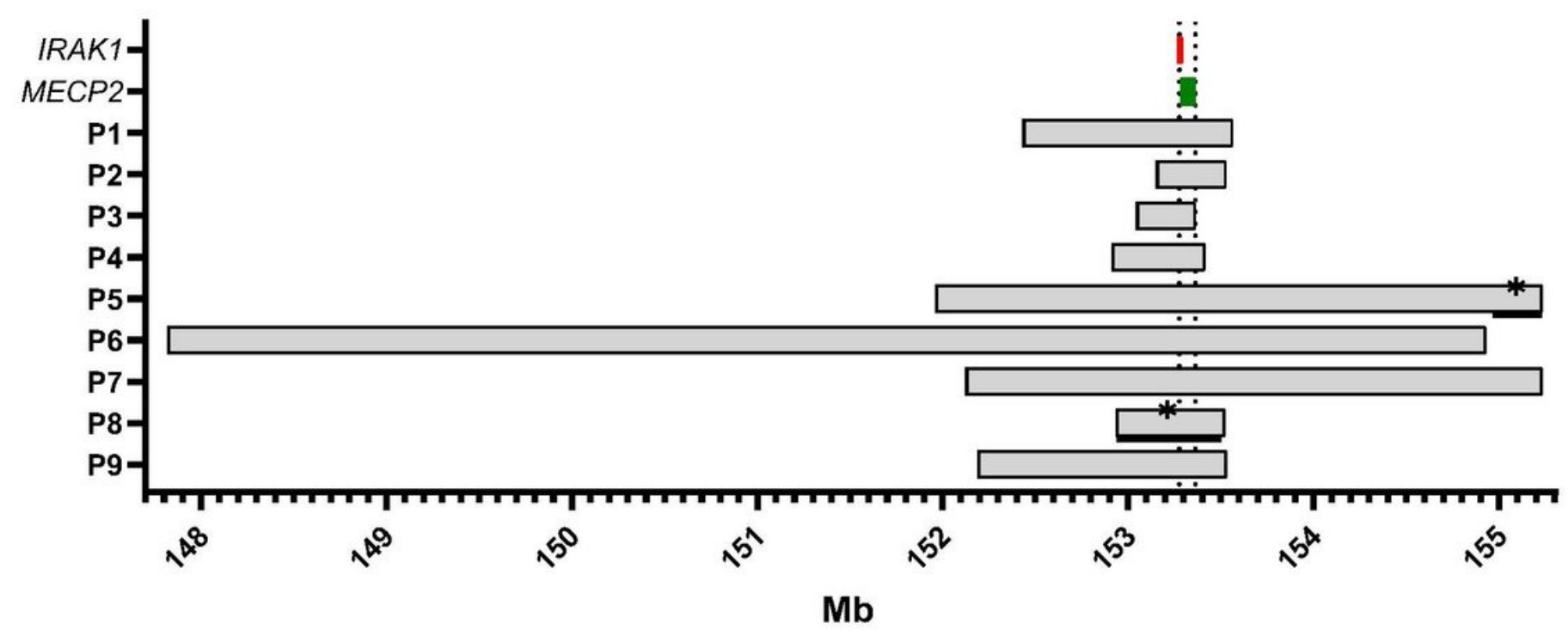

Figure 2

Size of duplications on chromosome Xq28 based on human genome assembly GRCh37 (hg19) in mega base pairs (Mb). Position of IRAK1 is indicated in red and position of MECP2 is indicated in green. Vertical dotted lines show the minimal duplicated region including IRAK1 and MECP2. * Black bars with a star indicate triplicated segments. This figure was created using Prism 9 (GraphPad). 


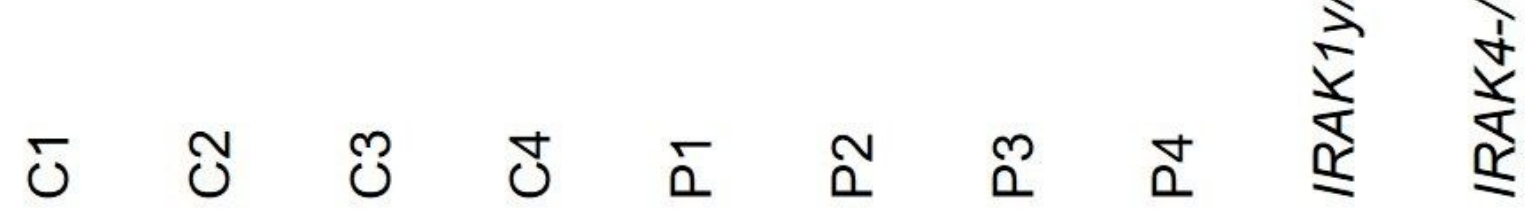

IRAK1

IRAK4 GAPDH

Figure 3

Characterization of SV40-immortalized fibroblasts. Western blot analysis of IRAK-1 and IRAK-4 protein levels in cell lysates from SV40-immortalized fibroblasts of healthy controls $(n=4)$, patients $(n=4)$, an IRAK1-deficient patient and an IRAK4-deficient patient. Pictures were cropped and adjusted. Quantitation is shown in Table $\mathrm{S} 2$. 
- Healthy controls

- Patients

- IRAK1 y/-
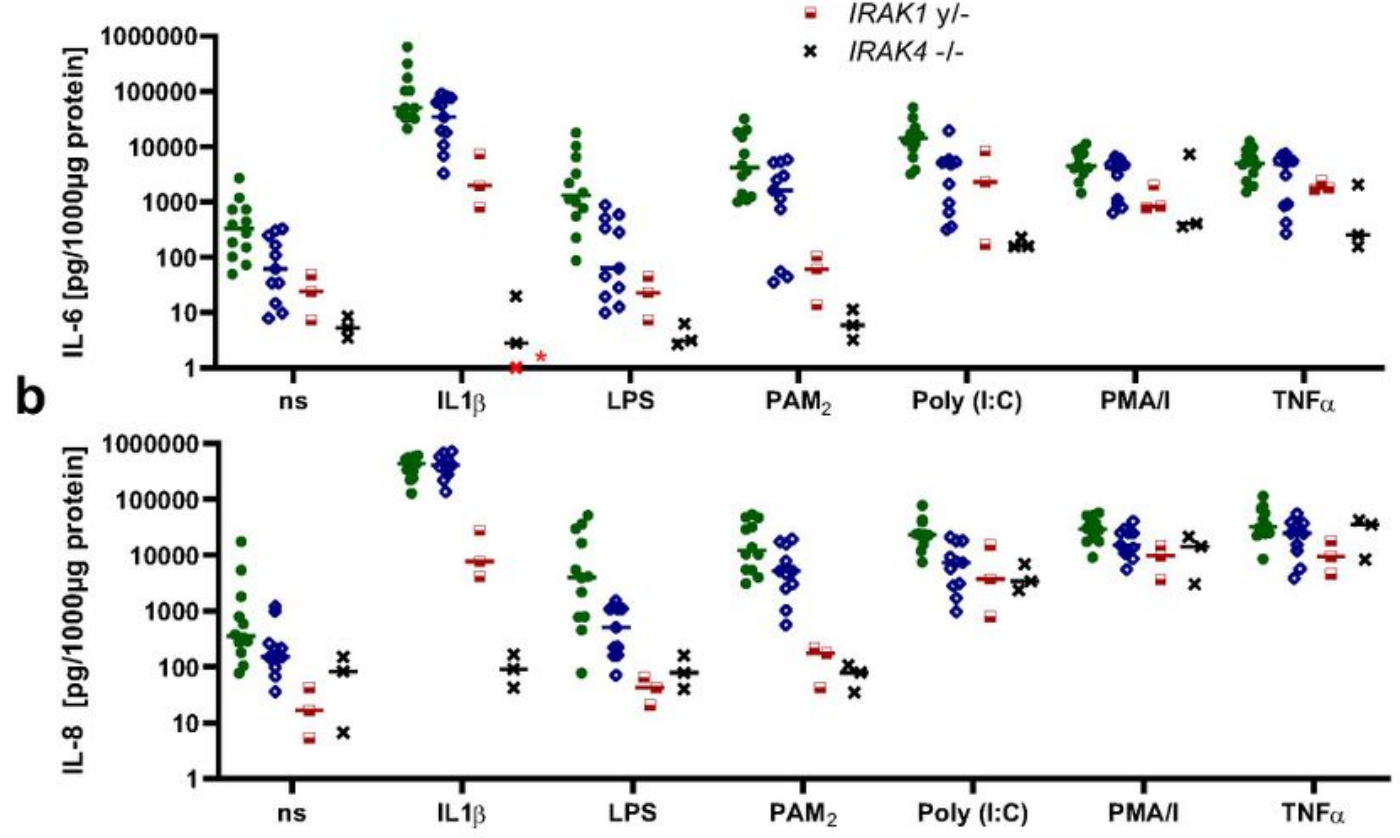

C

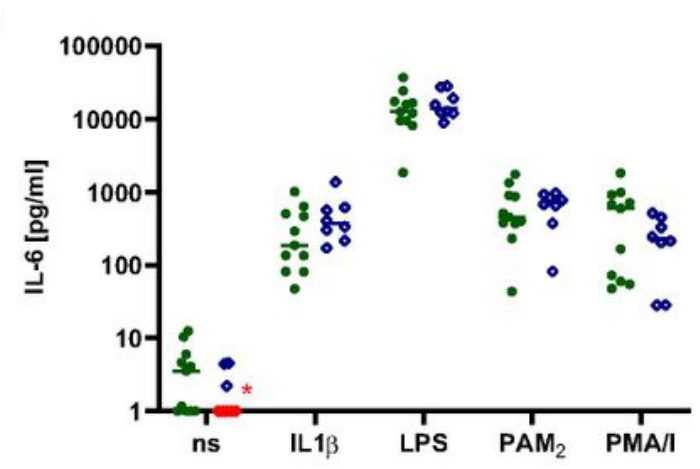

d Healthy controls

- Patients

e
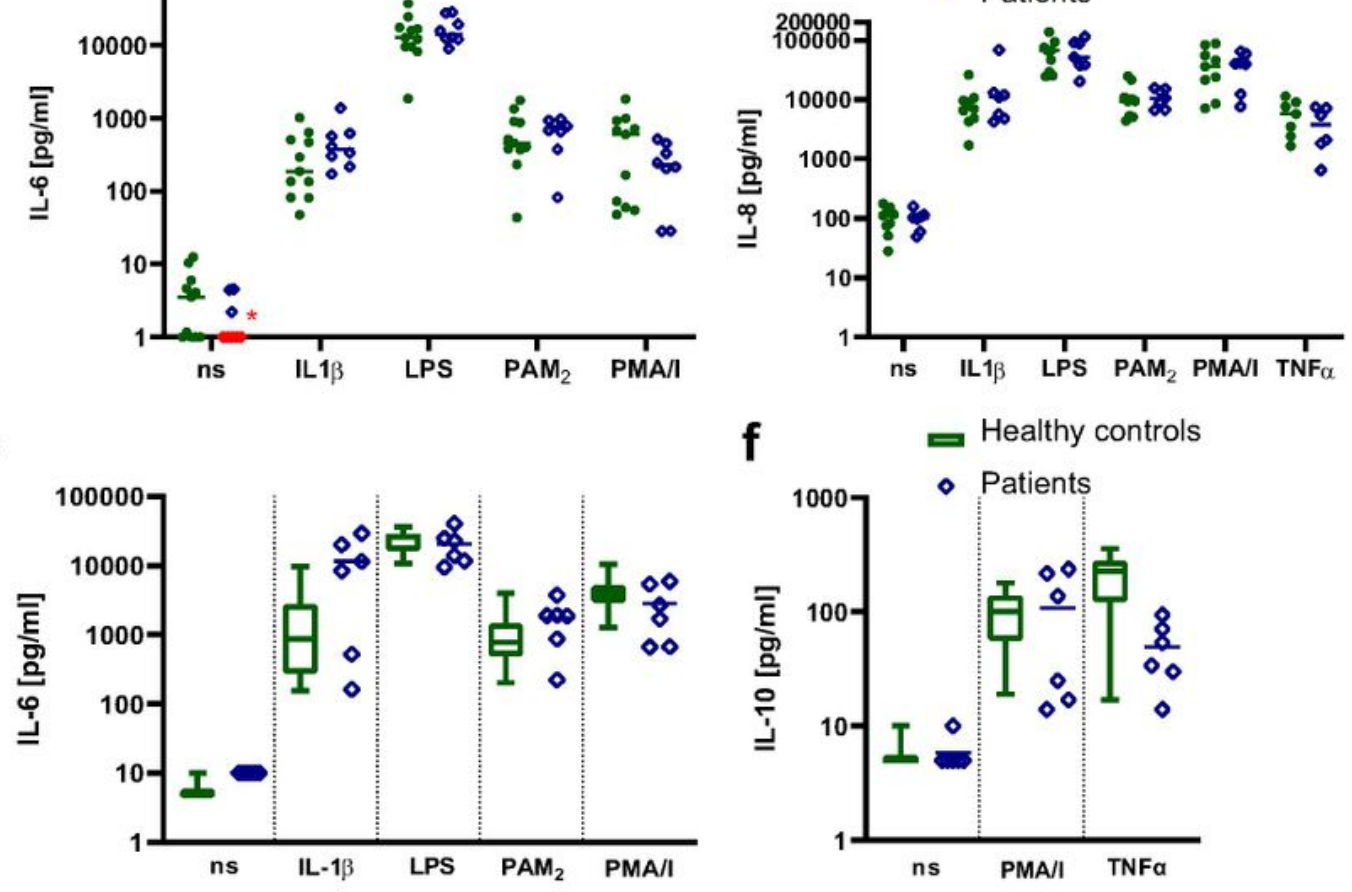

f $\quad$ Healthy controls

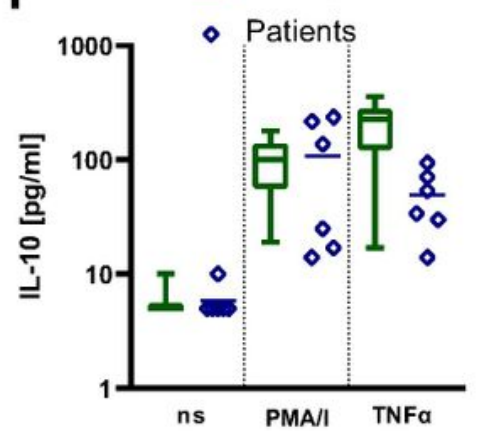

\section{Figure 4}

Cytokine production upon stimulation measured in cell culture supernatants. Bars indicate median values. $a$ and b Cytokine production in patients' SV40-immortalized fibroblasts $(n=4)$ upon stimulation with IL-1 $\beta(0,1 \mathrm{ng} / \mathrm{ml})$, TLR-agonists (LPS for TLR4 $(10 \mu \mathrm{g} / \mathrm{ml}), \mathrm{PAM}_{2} \mathrm{CSK}_{4}$ for TLR2/TLR6 (10 $\left.\mu \mathrm{g} / \mathrm{ml}\right)$, Poly(I:C) for TLR3 $(25 \mu \mathrm{g} / \mathrm{ml}))$, PMA/lono $\left(1 \times 10^{-7} \mathrm{M} / 1 \times 10^{-5} \mathrm{M}\right)$ and TNF-a $(20 \mathrm{ng} / \mathrm{ml})$. SV40-immortalized fibroblasts of healthy controls $(\mathrm{n}=4)$, an IRAK1-null patient and an IRAK4-null patient were used as intra- 
assay controls. a IL-6 production. b IL-8 production. $\mathrm{c}$ and d Cytokine production in patients' PBMCs upon stimulation with IL-1 $\beta(1 \mathrm{ng} / \mathrm{ml})$, TLR-agonists (LPS for TLR4 (1ng/ml), PAM ${ }_{2} \mathrm{CSK}_{4}$ for TLR2/TLR6 $(1 \mu \mathrm{g} / \mathrm{ml}))$, PMA/lono $\left(1 \times 10^{-7} \mathrm{M} / 1 \times 10^{-5} \mathrm{M}\right)$ and TNF-a $(20 \mathrm{ng} / \mathrm{ml})$. SV40-immortalized fibroblasts of healthy controls $(n=4)$ were used as intra-assay controls. c IL-6 production $(n=8)$. d IL-8 production $(n=7)$. * zero values. e and $f$ Cytokine production in patients' whole blood $(n=6)$ upon stimulation with IL-1 $\beta$ (20ng/ml), TLR-agonists (LPS for TLR4 (1ng/ml), PAM $2 \mathrm{CSK}_{4}$ for TLR2/TLR6 (100ng/ml)), PMA/lono $\left(1 \times 10^{-7} \mathrm{M} / 1 \times 10^{-5} \mathrm{M}\right)$ and TNF-a $(20 \mathrm{ng} / \mathrm{ml})$. The analyses were performed in comparison to a cohort of healthy controls assessed in our laboratory $(n=179$, whiskers $5-95$ percentile). e IL-6 production. $f$ IL-10 production. This figure was created using Prism 9 (GraphPad). IRAK1, IL-1 receptor-associated kinase 1; IL-1 $\beta$, interleukin-1 $\beta$; LPS, lipopolysaccharide; $\mathrm{PAM}_{2}, \mathrm{PAM}_{2} \mathrm{CSK}_{4} ; \mathrm{PMA} / \mathrm{I}$, phorbol myristate acetate/ ionomycin; TLR, toll-like receptor; TNF-a, tumor necrosis factor a 


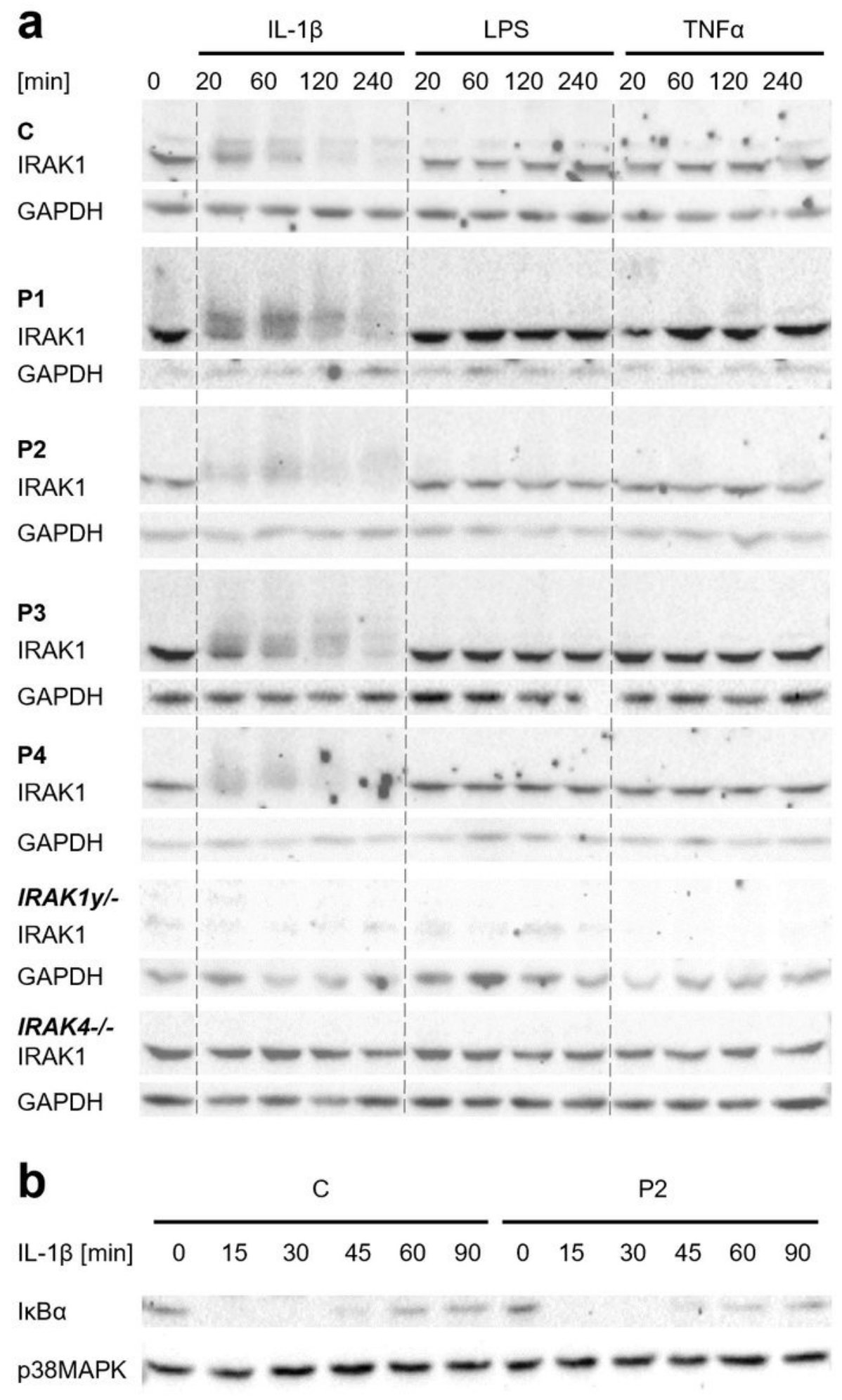

\section{Figure 5}

Immunological phenotype of SV40-immortalized fibroblasts. a IRAK1 phosphorylation upon stimulation with IL-1 $\beta(10 \mathrm{ng} / \mathrm{ml})$, TLR4-agonist LPS $(10 \mu \mathrm{g} / \mathrm{ml})$ and TNF-a $(20 \mathrm{ng} / \mathrm{ml})$. Cell lysates were analyzed by performing western blots specific to IRAK1, IKBa and GAPDH. Phosphorylated IRAK1 can be seen as smear above the band of the non-phosphorylated IRAK1. GAPDH was used as a loading control. b IKBadegradation upon stimulation with IL-1 $(10 \mathrm{ng} / \mathrm{ml})$. Cell lysates were analyzed by performing western 
blots specific to IKBa and p38MAPK. P38MAPK was used as a loading control. Pictures were cropped and adjusted. IRAK1, IL-1 receptor-associated kinase 1; IKBa, NF-KB inhibitor a; GAPDH, glyceraldehyde-3phosphate-dehydrogenase; IL-1 $\beta$, interleukin-1 $\beta$; LPS, lipopolysaccharide; p38MAPK, p38-mitogen activated protein kinase; TNF- $a$, tumor necrosis factor $a$

\section{Supplementary Files}

This is a list of supplementary files associated with this preprint. Click to download.

- SupplementaryMaterial.pdf 